\title{
Santa Catarina na rota da aviação comercial (1927-1949)1
}

\author{
Santa Catarina on the commercial aviation route (1927-1949) \\ Alcides Goularti Filho* \\ https://orcid.org/0000-0002-0808-4486
}

\begin{abstract}
Resumo
Este artigo relata e analisa a trajetória da aviação comercial em Santa Catarina entre os anos de 1927 e 1949, compreendendo o início das operações da Syndicato Condor na linha entre Rio de Janeiro e Porto Alegre (1927), com escalas em São Francisco do Sul e Florianópolis, até a fundação da Transportes Aéreos Catarinense (TAC) (1949). O artigo está dividido em quatro tópicos. O primeiro aborda o fenômeno da concentração aeroportuária e a litoralização descentralizada em Santa Catarina. Em seguida, é realizado uma descrição das vias de comunicações e dos meios de transportes em Santa Catarina dentro dos seus sistemas regionais de economia. O terceiro tópico relata a presença das companhias aéreas no território catarinense destacando suas escalas e horários. Por fim, o artigo trás breves considerações finais.
\end{abstract}

Palavras-chaves: aviação; transporte; território; economia; Santa Catarina

\begin{abstract}
This article reports and analyzes the trajectory of commercial aviation in Santa Catarina between the years 1927 and 1949, including the start of operations of Syndicato Condor on the line between Rio de Janeiro and Porto Alegre (1927), with stopovers in São Francisco do Sul and Florianópolis, until the foundation of Transportes Aéreos Catarinense (TAC) (1949). The article is divided into four topics. The first addresses the phenomenon of airport concentration and decentralized coastalization in Santa Catarina. Then, a description of the means of communication and means of transport in Santa Catarina is made within its regionais economic systems. The third topic reports the presence of airlines in Santa Catarina territory highlighting their scales and schedules. Finally, the article presents brief closing remarks.
\end{abstract}

Keywords: aviation; transport; territory; economy; Santa Catarina

\footnotetext{
${ }^{1}$ Pesquisa Financiada pela FAPESC.

* Doutor em Economia pela Universidade Estadual de Campinas (UNICAMP). Professor da Universidade do Extremo Sul Catarinense (UNESC). E-mail: alcides@unesc.net
} 


\section{Introdução: pioneiros do ar}

A história da aviação nas duas primeiras décadas, desde o dia 23 de outubro de 1906, quando Santos Dumont fez voar pelos céus de Paris o 14 Bis, é marcada por rápidos avanços técnicos na arte de voar e pelo espírito de aventura de jovens aviadores. Após a invenção de Dumont, surgiram outros nomes famosos na história da aviação que realizaram façanhas ousadas, desafiando a Lei da Gravidade. Em 25 de junho de 1909, Louis Blériot fez a travessia do Canal da Mancha. Dez anos depois, o Atlântico foi vencido em 14 de junho de 1919 pela dupla John Alcock e Arthur Whitten Brown.2 Posteriormente aos grandes feitos realizados pelos corajosos aviadores, em seguida foram repostos novos desafios a serem superados. Estávamos vivendo a era dos "raids aéreos", com travessias continentais e oceânicas, como Roma-Tóquio, New York-Rio de Janeiro, Lisboa-Rio de Janeiro, Londres-Sidney, Londres-Cidade do Cabo e Huelva-Buenos Aires. O raid entre Lisboa e Rio de Janeiro foi realizado pela dupla portuguesa Gago Coutinho e Sacadura Cabral entre março e junho de 1922. Por fim, destaca-se a epopeica travessia de Nova York a Paris, sem parada, realizada por Charles Lindbergh em 20 de maio de 1927. Esses raids abriam caminhos para diversos serviços aéreos e testavam a capacidade de resistência dos pilotos e das aeronaves.

Além da área militar, o aprendizado da aviação foi repassado ao correio aéreo, um setor estratégico para os Estados concentrarem e difundirem informações. O correio aéreo começou na França, em 1918, com a criação da Société des Lignes Latécoère, na cidade de Toulouse. Nos anos de 1920, o serviço aéreo postal foi sendo implantado em diversos países, mas foi com a Latécoère que ele ganhou dimensão mundial, ligando os três continentes: Europa, África e América. Em 1928, a Latécoère mudou de nome para Compagnie Générale Aéropostale, tornando-se uma referência mundial no correio aéreo. Se a França foi inovadora nessa área, a Alemanha foi pioneira no uso da aviação para o transporte de passageiros. Em 05 de fevereiro de 1919, a Deutsche Luft-Reederei inaugurou a linha Berlim-Weimer, com escala em Leipzig. Em seguida, em 22 de março do mesmo ano, foi realizado o primeiro voo comercial internacional entre Paris e Bruxelas, pela Avions Farman. 3

No Brasil, os raids começaram em 1912, quando o aviador Eduardo Pacheco Chaves, em 28 de abril, partiu da cidade de São Paulo, sobrevoou a Serra do Mar, pousando na cidade do Rio de Janeiro. Chaves também realizou

${ }^{2}$ TAYLOR, John William Ransom. A evolução da aviação. São Paulo: Melhoramentos, 1982. ${ }^{3}$ Ibidem. 
o difícil raid entre Rio de Janeiro e Buenos Aires, partindo da capital brasileira em 25 de dezembro de 1920, chegando à cidade portenha em 29 de dezembro, com escalas em São Paulo, Guaratuba, Porto Alegre e Montevidéu. ${ }^{4}$

Os serviços postais aéreos no território brasileiro também começaram com a Compagnie Générale Aéropostale em 1928. Inicialmente, esse serviço foi regulamento por meio do Decreto oํ 18.009, de 06 de dezembro de 1927, que autorizou a Compagnie Générale d'Entreprises Aéronautiques (sucessora da Société des Lignes Latécoère) a funcionar no Brasil. Em seguida, em 14 de fevereiro de 1928, por meio do Decreto $n^{\circ}$ 18.113, a autorização foi repassada para Compagnie Générale Aéropostale (sucessora da Compagnie Générale d'Entreprises Aéronautiques). A Aéropostale entrou em operação no Brasil no dia 01 de março de 1928, fazendo a longa rota entre Natal e Buenos Aires, com paradas nas principais cidades do litoral brasileiro e em Montevidéu. A Aéropostale atuou no serviço postal aéreo entre Europa e América do Sul até o ano de 1933, quando foi adquirida pela recém-criada Air France. Com o armistício de 22 de junho de 1940 entre a França e a Alemanha, a Air France suspendeu os serviços postais para a América do Sul.

A aviação comercial no Brasil começou por duas vias: a interna, com a fundação da Viação Aérea Rio-Grandense (VARIG), na cidade de Porto Alegre, em 1927; e a externa, com a fundação da Syndicato Condor Ltda, na cidade de Berlim, em 1927, pela Deutsche Lufthansa. A VARIG, durante a sua primeira década de existência, atuou como uma companhia regional, atendendo a diversas cidades do Rio Grande do Sul. A Syndicato Condor foi uma companhia multinacional, que rapidamente ampliou sua frota e suas linhas na América do Sul. Em 1930, chegou ao continente sul-americano a Pan American Airways, por meio da aquisição da maioria das ações da New York Rio Buenos Aires Line, uma empresa estadunidense que havia começado suas operações em agosto de 1929 e era responsável pela cobertura aérea do Chile, da Argentina, do Uruguai, do Brasil e da Venezuela, com destino ao Caribe e aos Estados Unidos.

Nos anos de 1930, o mercado aéreo sul-americano passou a ser disputado entre quatro grandes companhias aéreas, a alemã Lufthansa (Syndicato Condor), a estadunidense Pan American (Panair), a italiana Ala Litoria e a francesa Air France (Aeropostale). Entre as companhias aéreas nacionais, além da VARIG, destaca-se também o surgimento da Viação Aérea São Paulo (VASP), em 1933.

${ }^{4}$ O JORNAL. Edú Chaves venceu o raid Rio-Buenos Aires: a grande prova foi conquistada em cinco etapas. Rio de Janeiro, 30/12/1920. Disponível em: <http://bndigital.bn.gov.br/hemeroteca-digital/>. Acesso em: abr. 2020. 
O transporte ferroviário e a navegação ditaram as orientações da política de transportes conduzida pela jovem República. Isso não anulou a utilização dos velhos caminhos e das estradas que cortavam boa parte do território nacional, integrando cidades e regiões carentes de ferrovias e portos. A literatura mais convencional sobre a história dos transportes define que, a partir dos anos de 1940, o Brasil vivenciou a chamada "era rodoviária". A massificação do automóvel e a abertura de grandes rodovias, ambas inseridas em planos governamentais, aceleraram os fluxos no território nacional. Todavia, paralela a esse movimento, ocorreu a difusão da aviação regional brasileira, por meio da presença de diversas companhias aéreas que decolavam e pousavam em aeroportos e aeródromos (campos de aviação) construídos e abertos nas capitais e em diversas cidades do interior do País. Talvez melhor fosse dizer que vivemos concomitantemente à "era" rodoviária e aeroviária. No entanto, quando comparamos o volume de passageiros transportados no ferroviário e no aeroviário nos anos de 1930 e 1940, há uma predominância do primeiro, porém com taxas decrescentes, ao contrário do aeroviário, que apresentava taxas consideráveis de crescimento, tanto no número de passageiros como no de cargas.

A constituição do sistema nacional de economia - fundado na integração do mercado interno, com uma ampla rede viária ligando as principais cidades e regiões -, de um sistema de comunicação (correios, telégrafo e telefonia) que possibilitava a difusão de informações em todo o território nacional e de uma rede de eletrificação que ganhava contornos nacionais - alimentada pelas grandes companhias estatais de geração, transmissão e distribuição de energia - formava a base da industrialização pesada. O País crescia em quase todas as regiões, e, além das capitais dos estados da federação, outras cidades do interior do País também viviam momentos de rápida expansão urbana e demográfica. Portanto, a industrialização, a formação do mercado interno e a urbanização criavam as condições materiais favoráveis para a expansão da aviação regional.

Do ponto de vista jurídico, podemos destacar a criação de duas instituições que definiram as bases do setor aéreo brasileiro. 0 primeiro foi o Decreto no 16.983, de 22 de julho de 1925, ${ }^{5}$ que aprovou o Regulamento dos Serviços Civis de Navegação Aérea e organizou o papel dos aeronautas, das aeronaves, do tráfego aéreo, das concessões da navegação aérea e da organização dos

\footnotetext{
${ }^{5}$ Decreto $n^{\circ}$ 16.983, de 22 de julho de 1925. Brasília: Câmara dos Deputados. Disponível em: <https://www2. camara.leg.br/atividade-legislativa/legislacao>. Acesso em: março/2020.
} 
serviços de terra. O segundo foi o Decreto no 19.902, de 22 de abril de 1931, ${ }^{6}$ que criou o Departamento de Aeronáutica Civil (DAC), o qual regulamentou os serviços aéreos e disciplinou as companhias. Outro fato relevante para a aviação brasileira foi a criação do Ministério da Aeronáutica por Getúlio Vargas, por meio do Decreto-Lei n 2.961, de 20 de janeiro de $1941 .{ }^{7}$

O objetivo deste artigo é descrever a trajetória inicial da aviação comercial em Santa Catarina, destacando a atuação das primeiras companhias aéreas que realizavam escalas nas cidades catarinenses para embarque e desembarque de passageiros e cargas. O período analisado compreende os anos entre 1927 e 1949. O ano de 1927 está relacionado com o início das operações da empresa alemã Syndicato Condor Ltda, que foi a primeira companhia aérea a realizar voos comerciais no Brasil na rota Rio de Janeiro a Porto Alegre, com escalas em Santa Catarina, nas cidades de Florianópolis e São Francisco do Sul, no dia 01 de junho. Em 1949, foi fundada a Transportes Aéreos Catarinense (TAC), que alterou o quadro aéreo em Santa Catarina, inaugurando diversos voos regionais. Portanto, o período compreende o início da aviação comercial (1927) ao início da aviação regional em Santa Catarina (1949). Como fonte de pesquisa, utilizaram-se, em larga medida, os periódicos disponíveis na Hemeroteca Digital da Biblioteca Nacional do Rio de Janeiro e na Hemeroteca Digital de Santa Catarina. Entre os periódicos mais utilizados, destacam-se O Estado, República e A Notícia, todos de Santa Catarina, e O Jornal e Gazeta de Notícias, ambos do Rio de Janeiro, além de outros periódicos de Curitiba e São Paulo, como também o Diário Oficial da União.

A narrativa dos acontecimentos que envolveram a história da aviação em Santa Catarina entre 1927 e 1949 é enriquecida com uma abordagem crítico-social, fundada na heterodoxia econômica, na geografia crítica e na história econômica. A partir dos marcos referenciais do livro "Formação econômica de Santa Catarina", ${ }^{8}$ neste artigo, busco compreender a história econômica da aviação comercial em Santa Catarina, iniciando por meio da litoralização da economia catarinense e da sobreposição das camadas geoeconômicas inseridas nos sistemas regionais de economia. A combinação desses processos constitui diferentes formas de adensamento do Estado e do capital no território. Este artigo apresenta uma contribuição inédita para a historiografia econômica catarinense a partir de categorias inovadoras.

\footnotetext{
${ }^{6}$ Decreto $n^{\circ}$ 19.902, de 22 de abril de 1931. Brasília: Câmara dos Deputados. Disponível em: <https://www2. camara.leg.br/atividade-legislativa/legislacao>. Acesso em: março/2020.

${ }^{7}$ Decreto-Lei n².961, de 20 de janeiro de 1941. Brasília: Câmara dos Deputados. Disponível em: <https://www2. camara.leg.br/atividade-legislativa/legislacao>. Acesso em: março/2020.

${ }^{8}$ GOULARTI FILHO, Alcides. Formação econômica de Santa Catarina. Florianópolis: Editora da UFSC, 2016.
} 


\section{Concentração aeroportuária e litoralização descentralizada}

Quando observadas as páginas finais da revista de bordo da Latam, da Gol ou da Azul, sempre encontramos um mapa com as rotas das companhias. Comparando Santa Catarina com os demais estados da federação, percebe-se que próximo ao litoral há uma concentração de aeroportos: Jaguaruna (até 2014, o aeroporto do sul catarinense se situava em Criciúma), Florianópolis, Navegantes e Joinville. Essa concentração aeroportuária está relacionada com o processo de litoralização da economia catarinense, que ocorreu (e vem ocorrendo) na grande área litorânea que abrange os litorais sul e leste e o litoral norte. A litoralização resultou de um processo histórico de sobreposição de diferentes formas de adensamento do Estado e do capital no território. Podemos definir essas formas de adensamento como: a) movimento demográfico (ocupação territorial, colonização, imigração e migração); b) urbanização (fundação de vilas e colônias e expansão da malha urbana); c) formação do sistema regional de economia (complexos regionais, polos e setores produtivos); d) sobreposição de camadas geoeconômicas (transportes, comunicações, energia e abastecimentos); e f) institucionalização das esferas da existência (escolas, igrejas, partidos, sindicatos e associações). Em última instância, são essas formas que garantem a valorização máxima do valor. Portanto, a litoralização é uma manifestação concentrada de formas de adensamento.

Relacionadas aos transportes, as camadas geoeconômicas são um tipo de adensamento formado por disponibilidades materiais que possibilitam a realização de fluxos. Enquanto forma específica, elas assumem uma magnitude diferenciada ao longo do tempo, acelerando fluxos. Há uma estreita relação entre a litoralização e a sobreposição das camadas geoeconômicas. Portanto, as camadas são formas de adensamento e a litoralização é a manifestação concentrada das formas.

Enquanto forma de adensamento os sistemas regionais de economia, os quais são compostos por complexos regionais (agrário, extrativista e industrial), polos industriais e setores produtivos. No interior dos sistemas regionais, a produção e a circulação se organizam, definindo em territórios as especialidades regionais, a diversificação econômica, a articulação comercial e a integração produtiva. Os sistemas regionais de economia criam as disponibilidades materiais necessárias para a formação e a consolidação dos complexos regionais. Simultaneamente, no interior dos sistemas regionais, combinam e se desenvolvem diversas formas de adensamento. Portanto, podemos definir os complexos regionais com uma derivação dos sistemas regionais de economia circunscrita no território. 
Nossa pesquisa sobre a aviação em Santa Catarina no período de 1927 a 1949, que abrange desde a introdução da rota comercial iniciada pelo Syndicato Condor à fundação da Transportes Aéreos Catarinense (TAC), tem como categorias de análise as camadas geoeconômicas que foram postas ao longo da grande área litorânea catarinense, na qual temos a presença de complexos regionais e setores produtivos. A aviação, por meio das rotas e das linhas aéreas, é um tipo específico de camada geoeconômica, pois utiliza o espaço aéreo para realizar parcialmente seus fluxos, porém está presa a pontos fixos no território (aeroportos) para concluir seus fluxos.

Como em toda a Colônia, a ocupação do território na Capitania de Santa Catarina, no meado do século XVII, começou pelo litoral com a fundação das vilas de São Francisco do Sul, Desterro (Florianópolis) e Laguna. No meado do século XVIII, ao lado das comunidades indígenas que foram sendo dizimadas, o povoamento do litoral foi reforçado com a imigração açoriana, que foi assentada nessa mesma faixa litorânea onde habitavam os Carijós. A colonização do século XIX também priorizou essa área com algumas incursões aos vales dos rios Urussanga, Tubarão, Itajaí-Açu e Itapocu. A ocupação demográfica promoveu o extermínio dos indígenas e exigia condições materiais de sobrevivência para os novos colonizadores, que resultou em uma sequência de investimentos estatais que possibilitavam a reprodução ampliada do capital e a sociabilidade moderna. No século XIX, podemos citar a criação da linha postal entre São Francisco do Sul, Desterro e Laguna, em 1839; a abertura da Estrada do Litoral, em 1856; o assentamento da rede de telégrafo, que ligou Laguna a São Francisco do Sul, em 1867; a inauguração da Estrada de Ferro Dona Teresa Cristina, em 1884; e os melhoramentos nos portos de Laguna, Desterro, Itajaí e São Francisco do Sul. No século XX, surgiram novas demandas que exigiram mais investimentos para manter a reprodução da existência econômica e social, como a construção de ferrovias (Estrada de Ferro Santa Catarina, no Vale do Itajaí, e o tronco da Estrada de Ferro São Paulo-Rio Grande, entre São Francisco do Sul e Porto União), a abertura de novas estradas, o reaparelhamento dos portos (incluído Imbituba), a implantação da rede telefônica entre Criciúma e Joinville (investimentos privados da Companhia Telefônica Catarinense), a ampliação da rede de eletrificação a partir da Termoelétrica Jorge Lacerda e da Centrais Elétricas de Santa Catarina (CELESC), e a pavimentação da BR-101.

O conjunto dessas disponibilidades materiais forma camadas geoeconômicas que adensam o Estado no território, possibilitam a reprodução ampliada do capital e garantem a sociabilidade moderna. Sendo assim, a litoralização 
é um processo histórico que foi sendo construído e reposto por meio da combinação e da sobreposição das diversas camadas. Em Santa Catarina, a litoralização criou uma tríade territorial fundada na cidade administrativa (Florianópolis), nas cidades industriais (Criciúma, Blumenau, Jaraguá do Sul e Joinville) e nas cidades portuárias (Laguna, Imbituba, Itajaí e São Francisco do Sul). Quando comparamos a ocupação demográfica e econômica da faixa litorânea de Santa Catarina com a de outros estados da federação, podemos concluir que a formação da tríade territorial e a disponibilidade das camadas geoeconômicas resultaram, em Santa Catarina, em uma litoralização descentralizada. O grau de concentração da litoralização é melhor identificado quando olhamos a partir de escalas. Do ponto de vista estadual, a litoralização em Santa Catarina é uma concentração econômica, social e urbana. Porém, quando aproximamos a escala para mesorregional, vemos que ela está desconcentrada em quatro regiões: litoral sul, leste, baixo Vale do Itajaí e litoral norte.

É dentro desse processo histórico, que resultou na litoralização descentralizada, que podemos entender a concentração aeroportuária em Santa Catarina. Em 1928, a Syndicato Condor, na linha entre Rio de Janeiro e Porto Alegre, fazia escalas em São Francisco do Sul, Itajaí, Florianópolis e Laguna. A Aerolloyd Iguassu começou operando em Santa Catarina em 1933, realizando voos de São Paulo a Florianópolis, com escalas em Curitiba, Joinville, Blumenau e Itajaí. A Viação Aérea Rio-Grandense (VARIG) começou a operar em Florianópolis em 1946. Em seguida, já estava realizando voos para Joinville, Itajaí e Araranguá. No final da década de 1940, a Transportes Aéreos Bandeirantes Ltda (TABA) atendia às cidades de Araranguá, Laguna, Florianópolis, Itajaí e São Francisco do Sul. Por fim, em 1949, entrou em operação a Transportes Aéreos Catarinense (TAC), que cobria as principais cidades catarinenses até sua extinção em 1966.

\section{Transportes e economia catarinense}

Dentro da formação econômica de Santa Catarina (os anos de 1930 e 1940), podemos observar a presença de três economias que se combinavam: a pequena produção mercantil, o setor exportador (madeira, erva-mate e carvão) e a nascente média indústria voltada para o mercado nacional. Além das exportações lideradas pelo setor agrário e extrativista (principalmente madeira, carvão e erva-mate), também se destacavam as exportações de produtos têxteis e alimentícios. Nas áreas de colonização, a presença da pequena 
produção mercantil ainda persistia, sendo responsável pela dinamização das economias regionais do litoral e planalto norte, Vale do Itajaí e sul catarinense. Contudo, a novidade pós-1930 na economia catarinense foi o nascimento de uma dinâmica indústria metalmecânica localizada em Joinville. ${ }^{9}$

No planalto norte, o complexo ervateiro apresentava sinais de esgotamento, e o capital acumulado começava a se desdobrar em outras atividades produtivas, como a indústria madeireira. No grande oeste, as atividades madeireiras pautadas na extração da araucária viviam seu período áureo, e, paulatinamente, a pequena indústria alimentar, fundada nos frigoríficos de abate de suínos e aves, dava seus primeiros passos na formação de um complexo agrocomercial. No Vale do Itajaí, área de colonização europeia e da pequena produção mercantil, o comando da acumulação era exercido pela indústria têxtil e do vestuário, além da presença de uma base produtiva bem diversificada. Por fim, no sul catarinense, estava em marcha a formação do complexo carbonífero integrado à economia nacional.

Santa Catarina chega a 1945 com uma base produtiva diversificada e com tendências à sua ampliação. Essas condições concretas da vida material, aos poucos, emergiam no seio da economia e da sociedade catarinense nos anos de 1930 e início da década de 1940. As velhas atividades mercantis, agrárias e extrativas começavam a ceder lugar para a indústria cerâmica no Sul, a indústria de papel e pasta mecânica no planalto serrano e a indústria metalmecânica em Joinville. ${ }^{10}$

O romper de uma nova base material exigia melhoramentos e mais investimentos nas camadas geoeconômicas. No setor de transportes, durante o governo de Nereu Ramos, no ano de 1936, foi elaborado o primeiro Plano Rodoviário Estadual, que definiu as áreas prioritárias de investimentos, classificando as estradas de primeira e de segunda classe. No setor privado de telefonia, a Companhia Telefônica Catarinense, fundada em 1927, nos anos de 1930, ampliou consideravelmente suas linhas, integrando Florianópolis ao litoral sul, planalto serrano e planalto norte. Por fim, no setor elétrico, destaca-se a fundação da Companhia de Luz e Força de Florianópolis, em 1910, que atuou na eletrificação da capital catarinense, e a Empresa Sul Brasileira de Eletricidade (Empresul), fundada em 1929, de capital alemão, localizada em Joinville, que se estendeu por todo o litoral e o planalto norte. A Força e Luz foi estatizada em 1935, e a Empresul em 1942. Ambas se constituíram

${ }^{9}$ Ibidem.

${ }^{10}$ Ibidem. 
em organizações empresariais com capacidade de planejar e imprimir novos ritmos ao setor elétrico catarinense. ${ }^{11}$

Nesse cenário de uma economia em consolidação de setores tradicionais e de surgimento de setores dinâmicos que tiveram início os voos para Santa Catarina. As escalas realizadas em Laguna e Araranguá atendiam às demandas advindas das atividades carboníferas, uma vez que ambas as cidades eram integradas a Criciúma, Urussanga, Siderópolis e Tubarão por meio da Estrada de Ferro Dona Teresa Cristina. Em Itajaí, o fluxo de passageiros e de malas postais, em boa medida, dirigia-se a Blumenau, que se consolidava como "polo" regional da indústria têxtil e do vestuário, por meio da navegação fluvial do rio Itajaí-Açu. As escalas em São Francisco do Sul eram compartilhadas com Joinville - o centro financeiro e comercial do complexo ervateiro catarinense, no qual era possível chegar via Estrada de Ferro São Paulo-Rio Grande ou por meio da navegação fluvial no rio Cachoeira. Portanto, as cidades que recebiam escalas aéreas em Santa Catarina estavam integradas com sua hinterland por meio de ferrovias ou da navegação fluvial. Já era possível identificar na história da aviação catarinense a combinação de diversas modalidades de transportes presentes nas cidades industriais, que constituíam um dos pilares da tríade territorial: Joinville (complexo ervateiro), Criciúma (complexo carbonífero) e Blumenau (indústria têxtil e do vestuário).

A combinação das diversas disponibilidades materiais - as camadas geoeconômicas e as atividades agrária, extrativista e industrial - formam os complexos regionais como parte constitutiva do sistema regional de economia, os quais atuam com relativa capacidade endógena de acumulação. Sendo assim, as linhas áreas estabelecidas ao longo do litoral catarinense combinaram-se com a camadas geoeconômicas e possibilitaram integrar o movimento aeroportuário com os complexos regionais e os setores produtivos. Portanto, podemos definir que uma linha aérea é um tipo específico de camada geoeconômica.

\section{Companhias aéreas em Santa Catarina}

As três primeiras companhias aéreas que começaram a operar em Santa Catarina foram a Syndicato Condor Ltda, em 1927; a Compagnie Générale Aéropostale, em 1928; e a NYRBA do Brasil, em 1929 - todas eram de capital externo. A Aéropostale, no entanto, atuava apenas no transporte de malas

${ }^{11}$ GOULARTI FILHO, Alcides. Formação do complexo e do sistema estatal catarinense. In: VII Jornadas Uruguayas de História Económica. Montevidéu: AUDHE, dez. 2019. 
postais, portanto não será objeto de estudo desse artigo. Em seguida, vieram a Aerolloyd Iguassu, em 1933; a VARIG, em 1946; a Real, em 1947; e a TABA, em 1948. A Syndicato Condor foi nacionalizada em 1942 e passou a ser chamada Serviços Aéreos Cruzeiro do Sul. A NYRBA se converteu na Panair do Brasil, em 1930; e a Aerolloyd Iguassu foi adquirida pela VASP, em 1939. No quadro abaixo (Quadro 1) temo um panorama geral das companhias aéreas que realizaram escalas em Santa Catarina entre 1927 e 1949.

Quadro 1: Panorama geral das companhias aéreas que realizavam escalas em Santa Catarina 1927-1949

\begin{tabular}{|c|c|c|c|c|}
\hline $\begin{array}{l}\text { Companhia } \\
\text { aérea }\end{array}$ & $\begin{array}{c}\text { Início das } \\
\text { escalas em } \\
\text { Santa Catarina }\end{array}$ & Escalas realizadas & Sede & Observações \\
\hline $\begin{array}{l}\text { Syndicato } \\
\text { Condor }\end{array}$ & 01/06/1927 & $\begin{array}{l}\text { São Francisco } \\
\text { do Sul, Joinville, } \\
\text { Blumenau, Itajaí e } \\
\text { Florianópolis }\end{array}$ & Berlim & $\begin{array}{c}\text { Encampada em } \\
\text { agosto } 1942 . \\
\text { Patrimônio } \\
\text { incorporado pela } \\
\text { Serviços Aéreos } \\
\text { Cruzeiro do Sul. }\end{array}$ \\
\hline $\begin{array}{l}\text { Compagnie } \\
\text { Générale } \\
\text { Aéropostale }\end{array}$ & 01/03/1928 & Florianópolis & Toulouse & $\begin{array}{c}\text { Adquirida pela Air } \\
\text { France em } 1933 . \\
\text { Realizava apenas } \\
\text { serviços postais. }\end{array}$ \\
\hline $\begin{array}{l}\text { NYRBA do } \\
\text { Brasil }\end{array}$ & 08/01/1930 & Florianópolis & Delaware & $\begin{array}{c}\text { Adquirida pela Pan } \\
\text { American Airways } \\
\text { em agosto de } 1930 \\
\text { e passou a chamar } \\
\text { Panair do Brasil }\end{array}$ \\
\hline Panair do Brasil & 02/11/1931 & Florianópolis & Miami & $\begin{array}{c}\text { Em } 1965 \text { foi } \\
\text { decreta a falência } \\
\text { forçada }\end{array}$ \\
\hline $\begin{array}{l}\text { Aerolloyd } \\
\text { Iguassu }\end{array}$ & 18/07/1933 & $\begin{array}{l}\text { Joinville, Blumenau, } \\
\text { Itajaí e Florianópolis }\end{array}$ & Curitiba & $\begin{array}{c}\text { Adquirida pela } \\
\text { Vasp em outubro } \\
\text { de } 1939\end{array}$ \\
\hline $\begin{array}{l}\text { Viação Aérea } \\
\text { São Paulo } \\
\text { (Vasp) }\end{array}$ & $30 / 11 / 1939$ & $\begin{array}{c}\text { Joinville, Itajaí e } \\
\text { Florianópolis }\end{array}$ & $\begin{array}{l}\text { São } \\
\text { Paulo }\end{array}$ & $\begin{array}{l}\text { Interrompeu as } \\
\text { escalas em agosto } \\
\text { de } 1942 \text { e retornou } \\
\text { em junho de } 1964\end{array}$ \\
\hline
\end{tabular}


conclusão

\begin{tabular}{|c|c|c|c|c|}
\hline $\begin{array}{c}\text { Companhia } \\
\text { aérea }\end{array}$ & $\begin{array}{c}\text { Início das } \\
\text { escalas em } \\
\text { Santa Catarina }\end{array}$ & Escalas realizadas & Sede & Observações \\
\hline $\begin{array}{c}\text { Serviços Aéreos } \\
\text { Cruzeiro do Sul }\end{array}$ & $\begin{array}{c}\text { Setembro de } \\
1942\end{array}$ & $\begin{array}{c}\text { Joinville e } \\
\text { Florianópolis }\end{array}$ & $\begin{array}{c}\text { Rio de } \\
\text { Janeiro }\end{array}$ & $\begin{array}{c}\text { Adquirida pela } \\
\text { Varig em } 1975\end{array}$ \\
\hline $\begin{array}{c}\text { Viação Aérea } \\
\text { Rio-Grandense } \\
\text { (Varig) }\end{array}$ & $14 / 01 / 1946$ & $\begin{array}{c}\text { Joinville, Itajaí, } \\
\text { Florianópolis e } \\
\text { Araranguá }\end{array}$ & $\begin{array}{c}\text { Porto } \\
\text { Alegre }\end{array}$ & Operou até 2006 \\
\hline $\begin{array}{c}\text { Real } \\
\text { Aéreos }\end{array}$ & Junho de 1947 & $\begin{array}{c}\text { Florianópolis } \\
\text { Aértes }\end{array}$ & $\begin{array}{c}\text { São } \\
\text { Paulo }\end{array}$ & $\begin{array}{c}\text { Adquirida pela } \\
\text { Varig em } 1961\end{array}$ \\
\hline $\begin{array}{c}\text { Transportes } \\
\text { Bandeirantes } \\
\text { (TABA) }\end{array}$ & Abril de 1948 & $\begin{array}{c}\text { São Francisco } \\
\text { do Sul, Itajaí, } \\
\text { Florianópolis, } \\
\text { Laguna e Araranguá }\end{array}$ & $\begin{array}{c}\text { Rio de } \\
\text { Janeiro }\end{array}$ & $\begin{array}{c}\text { Adquirida pela } \\
\text { Vasp em } 1963\end{array}$ \\
\hline
\end{tabular}

Fonte: Elaboração própria com base nas pesquisas realizadas junto a Hemeroteca Digital da Biblioteca Nacional

O aumento de companhias aéreas pós-1945, tanto no Brasil como em nível mundial, tem uma relação direta com a grande oferta de aeronaves mais baratas e eficientes fabricadas nos Estados Unidos para uso militar durante a Segunda Guerra Mundial. Com destaque para o Douglas DC-3 e a sua versão militar Douglas C-47, ambos com capacidade para 32 passageiros, que segundo informações disponíveis no Wikipédia, foram fabricados, entre 1936 e 1950, pela Douglas Aircraft Company, ao todo, 26.253 unidades (16.079 e 10.174, respectivamente). Também aumentou a oferta de pilotos e técnicos especializados em aviação, além da ampliação da rede telegráfica e das pistas para pouso. 0 aumento na oferta dessas aeronaves facilitou e permitiu a criação de diversas companhias aéreas regionais de baixo custo.

\section{Syndicato Condor e Serviços Aéreos Cruzeiro do Sul}

\section{Syndicato Condor no Brasil}

Com o objetivo de expandir a presença alemã na América do Sul por meio da aviação comercial e do correio aéreo, no dia 05 de maio de 1924, foi fundada na Alemanha a Condor Syndikat, uma companhia aérea que nasceu com 
a participação da Sociedad Colombo-Alemana de Transportes Aéreos (SCADTA), com sede em Barranquilla, e da Deutscher Aero Lloyd, com sede em Berlim. Em 1926, a Deutscher se fundiu com a Junkers Luftverkehr, uma fabricante de aviões, formando a Deutsche Lufthansa, que passou a controlar as linhas aéreas no Brasil, no Uruguai e na Argentina, que seriam realizados pela nova companhia denominada Syndicato Condor Ltda, sem a participação da SCADTA. ${ }^{12}$ Portanto, a Condor, que começou operar no Brasil em 01 de junho de 1927, era uma subsidiária da Lufthansa independente da Condor Syndikat. Para regulamentar seus serviços no Brasil, em 20 de janeiro de 1928, foi publicado o Decreto $\mathrm{n}^{\mathrm{o}} 18.075,{ }^{13}$ que concedeu à companhia Syndicato Condor, representada no Brasil pela firma Herm Scoltz \& Cia, a permissão para estabelecer o tráfego aéreo em todo o território nacional, podendo estender seus voos até o Uruguai e a Argentina.

Inicialmente, a Syndicato Condor tinha um hidroavião Dornier Wal, o Atlântico, com capacidade de 12 passageiros, além das bagagens e das malas postais. Depois foram acrescidos na frota o Ipiranga, um Junker G-24, para 14 passageiros, e dois Dornier Wal, o Bartolomeu de Gusmão e o Santos Dumont (este último acidentado logo após o voo inaugural em 03 de dezembro de 1928). Em 1930, a frota era composta por quatro Junkers F-13 (Bandeirante, Blumenau, Iguaçu e Pirajá), dois Junkers G-24 (Potiguar e Ipiranga) e dois Dornier Wal (Atlântico e Guanabara) ${ }^{14}$. Em 1935, foram acrescidos na frota mais quatro Junkers Ju-52, com capacidade para 16 passageiros, além do trimotor hidroavião Riachuelo. ${ }^{15}$ No Quadro 2, temos uma descrição das rotas realizadas pela Condor quando da sua inauguração.

\footnotetext{
${ }^{12}$ DAVIES, Ronald Edward George. Airlines of Latin America Since 1919. Washington, DC: Smithsonian Institution Press, 1984.

${ }^{13}$ Decreto $n^{\circledR} 18.075$, de 20 de janeiro de 1928. Brasília: Câmara dos Deputados. Disponível em: <https://www2. camara.leg.br/atividade-legislativa/legislacao>. Acesso em: março/2020.

${ }^{14}$ O ESTADO. Serviços aéreos Condor: os aviões Condor. Florianópolis, 23/01/1930. Disponível em: <http:// bndigital.bn.gov.br/hemeroteca-digital/>. Acesso em: abr. 2020.

${ }^{15}$ O ESTADO. Serviço aéreo. Florianópolis, 09/05/1935. Disponível em: <http://bndigital.bn.gov.br/hemeroteca-digital/>. Acesso em: abr. 2020.

${ }^{16}$ O ESTADO. A Condor aumenta seu tráfego. Florianópolis, 29/06/1935. Disponível em: <http://bndigital. bn.gov.br/hemeroteca-digital/>. Acesso em: abr. 2020.
} 
Quadro 2: Destinos, preços e distância da Syndicato Condor Ltda em 1927

\begin{tabular}{|c|c|c|}
\hline Destinos & Preços & Distância (km) \\
\hline Rio-Santos & $280 \$ 000$ & 350 \\
\hline Rio-Paranaguá & $510 \$ 000$ & 640 \\
\hline Rio-São Francisco do Sul & $580 \$ 000$ & 730 \\
\hline Rio-Florianópolis & $710 \$ 000$ & 890 \\
\hline Rio-Porto Alegre & $970 \$ 000$ & 1.350 \\
\hline Rio-Rio Grande (via Pelotas) & $1.170 \$ 000$ & 1.630 \\
\hline Santos-Paranaguá & $230 \$ 000$ & 290 \\
\hline Santos-São Francisco do Sul & $300 \$ 000$ & 380 \\
\hline Santos-Florianópolis & $430 \$ 000$ & 540 \\
\hline Santos-Porto Alegre & $720 \$ 000$ & 1.000 \\
\hline Santos-Rio Grande (via Pelotas) & $920 \$ 000$ & 1.280 \\
\hline Paranaguá-São Francisco do Sul & $70 \$ 000$ & 90 \\
\hline Paranaguá-Florianópolis & $200 \$ 000$ & 250 \\
\hline Paranaguá-Porto Alegre & $570 \$ 000$ & 710 \\
\hline Paranaguá-Rio Grande (via Pelotas) & $790 \$ 000$ & 990 \\
\hline São Francisco do Sul-Florianópolis & $130 \$ 000$ & 160 \\
\hline São Francisco do Sul-Porto Alegre & $500 \$ 000$ & 620 \\
\hline São Francisco do Sul-Rio Grande (via Pelotas) & $720 \$ 000$ & 900 \\
\hline Florianópolis-Porto Alegre & $370 \$ 000$ & 460 \\
\hline Florianópolis-Rio Grande & $590 \$ 000$ & 740 \\
\hline Porto Alegre-Rio Grande (via Pelotas) & $220 \$ 000$ & 230 \\
\hline Fonte: & & \\
\hline
\end{tabular}

Fonte: REPÚBLICA. Diversas: Condor Syndikat. Florianópolis, 07/08/1927. Disponível em: <http://bndigital.bn.gov.br/hemeroteca-digital/>. Acesso em: abr. 2020.

Em 1942, a frota era composta por 28 aeronaves Junkers, que realizavam voos regulares para o Sul, Sudeste, Nordeste, Centro-Oeste e Norte, além de conexões para Argentina, Uruguai, Chile, Bolívia e Peru. Com a declaração de guerra à Alemanha em agosto 1942, a Condor foi incorporada ao patrimônio nacional e depois convertida na Serviços Aéreos Cruzeiros do Sul Ltda.

\section{Syndicato Condor em Santa Catarina}

Em Santa Catarina, a Lufthansa ensaiou seus primeiros voos na viagem realizada pelo Ministro da Viação e Obras Públicas, Victor Konder, 
acompanhado dos jornalistas Raul Portugal (Agência Americana) e Machado Florence (O Paiz) e do cinegrafista Alberto Botelho, a Santa Catarina, em 01 de janeiro de 1927, proveniente do Rio de Janeiro, com escalas em Santos, Itajaí e Florianópolis. ${ }^{17}$ No dia 27 de janeiro, o Ministro Victor Konder concedeu a autorização para a Condor realizar o tráfego aéreo. ${ }^{18}$ Após esse voo "inaugural", a Condor voltou a realizar outros pousos em Florianópolis, um no dia 28 de janeiro e outro em 09 de fevereiro, ambos com destino a Porto Alegre. ${ }^{19}{ }^{20}$ No dia 31 de maio, a Hoepcke \& Cia, representante da Condor em Florianópolis, anunciou o início dos voos provenientes do Rio de Janeiro, com escalas em Santos e Paranaguá, pelo hidroavião Ipiranga, e do Sul, pelo Atlântico, provenientes do Rio Grande, com escalas em Porto Alegre e Torres. ${ }^{21}$

Como programado, no dia 01 de junho de 1927, às 16h55 aterrissou na baía sul o Atlântico, sendo recebido por diversas autoridades e curiosos. Desembarcaram em Florianópolis os passageiros Kurt Batzdorff e Lili Batzdorff; seguiram adiante Arlindo Gomes, que desceria em Santos, e Joaquim Lopes Dias, sua esposa e duas filhas (um bebê de 17 meses e outra criança de 7 anos). Após a recepção, desembarque e abastecimento, o Atlântico decolou às $19 \mathrm{~h}$, seguindo rumo ao Norte. ${ }^{22}$ No dia 09 de junho, proveniente de Santos, às $15 \mathrm{~h} 30$, chegou a Florianópolis o hidroavião Ipiranga, transportando passageiros e a mala postal, inaugurando a linha Norte. No mesmo dia, às $20 \mathrm{~h}$, o Ipiranga partiu em direção a Porto Alegre. ${ }^{23}$ A escala em São Francisco do Sul, na Baía da Babitonga, além de atender às demandas da cidade portuária, possibilitava estabelecer contato com a vizinha cidade de Joinville, que era o centro comercial e financeiro do complexo ervateiro catarinense.

\footnotetext{
${ }^{17}$ REPÚBLICA. O arrojado voo do Sr. Ministro da Viação Victor Konder do Rio a Florianópolis. Florianópolis, 04/01/1927. Disponível em: <http://bndigital.bn.gov.br/hemeroteca-digital/>. Acesso em: abr. 2020.

${ }^{18}$ REPÚBLICA. Notícias. Florianópolis, 29/01/1927. Disponível em: <http://bndigital.bn.gov.br/hemeroteca-digital/>. Acesso em: abr. 2020.

${ }^{19}$ O ESTADO. Linha aérea entre o Rio Grande e o Rio: o Ministro da Viação já concedeu a necessária autorização. Florianópolis, 28/01/1927. Disponível em: <http://bndigital.bn.gov.br/hemeroteca-digital/>. Acesso em: abr. 2020.

${ }^{20}$ REPÚBLICA. Um avião nesta capital. Florianópolis, 10/02/1927. Disponível em: <http://bndigital.bn.gov. $\mathrm{br} /$ hemeroteca-digital/>. Acesso em: abr. 2020.

${ }^{21}$ REPÚBLICA. Anúncio da Syndicato “Condor”. Florianópolis, 31/05/1927. Disponível em: <http://bndigital. bn.gov.br/hemeroteca-digital/>. Acesso em: abr. 2020.

${ }^{22}$ REPÚBLICA. Amerissou ontem nesta capital o avião "Atlântico" da "Condor Syndicato". Florianópolis, 02/06/1927. Disponível em: <http://bndigital.bn.gov.br/hemeroteca-digital/>. Acesso em: abr. 2020.

${ }^{23}$ REPÚBLICA. Navegação aérea: a chegada do Ipiranga. Florianópolis, 10/06/1927. Disponível em: <http:// bndigital.bn.gov.br/hemeroteca-digital/>. Acesso em: abr. 2020.
} 
No dia 03 de novembro, proveniente de Itajaí, foi a vez do moderno hidroavião Santos Dumont aterrissar em Florianópolis às 18h15. Portanto, estava inaugurada também a escala em Itajaí, que não estava prevista na autorização inicial. No dia 04, no retorno ao Rio de Janeiro, novamente a Condor fazia uma escala em Itajaí, pousando na foz do rio Itajaí-Açu. ${ }^{24}{ }^{25}$ Por fim, o hidroavião Bartolomeu de Gusmão, da fabricante Dornier Wal, proveniente de São Francisco e de Itajaí, aterrissou em Florianópolis às 7 h30 da manhã do dia 03 de fevereiro de 1928, seguindo, no mesmo dia, às 9h30, em direção a Porto Alegre. ${ }^{26}$
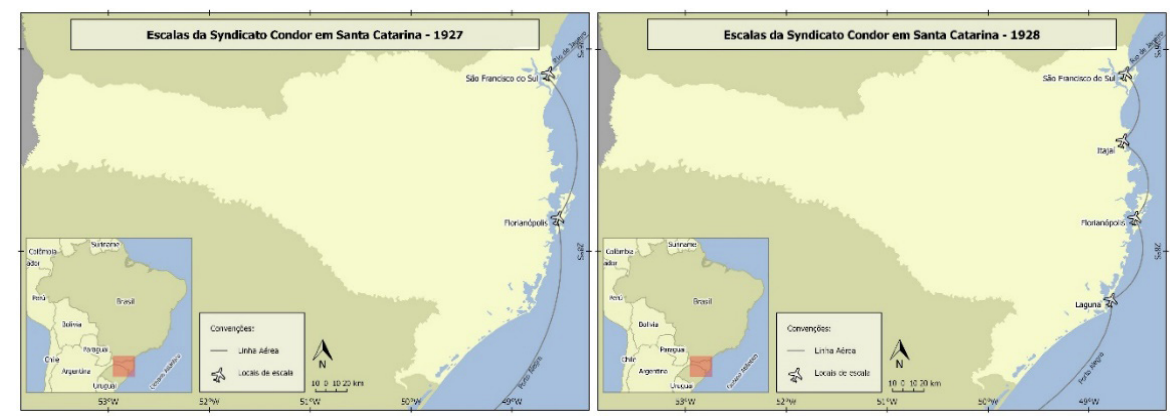

Em 06 de novembro de 1928, iniciaram as escalas em Laguna com a aterrissagem do hidroavião Braga, na lagoa do Santo Antônio dos Anjos. ${ }^{27}$ Portanto, o litoral catarinense, em 1928, já estava servido com linhas aéreas: Laguna, Florianópolis, Itajaí e São Francisco do Sul. As quatro escalas da Syndicato Condor no litoral catarinense combinaram com as outras camadas geoeconômicas que estavam disponíveis, formadas por estradas, navegação, linhas postais, telégrafos e telefonia. $\mathrm{O}$ agente Carlos Hoepcke S.A. ficou responsável pelos serviços de passagens e encomendas até o final dos anos de 1930. De acordo com a escala de horários dos voos que partiam do Rio de Janeiro (com destino a Porto Alegre) publicado no periódico carioca "O Jornal", a última escala da Condor em Itajaí foi em 08 de agosto de 1931; e em Laguna, 15 de

\footnotetext{
${ }^{24}$ REPÚBLICA. A viagem inaugural do hidroavião “Santos Dumont”. Florianópolis, 04/11/1927. Disponível em: <http://bndigital.bn.gov.br/hemeroteca-digital/>. Acesso em: abr. 2020.

${ }^{25}$ REPÚBLICA. A partida do Santos Dumont. Florianópolis, 05/11/1927. Disponível em: <http://bndigital. bn.gov.br/hemeroteca-digital/>. Acesso em: abr. 2020.

${ }^{26}$ REPÚBLICA. Diversas: hidroplano Bartolomeu de Gusmão. Florianópolis, 04/02/1928. Disponível em: $<$ http://bndigital.bn.gov.br/hemeroteca-digital/>. Acesso em: abr. 2020.

${ }^{27}$ REPÚBLICA. Aparelhos da Condor fazem voo na Laguna. Florianópolis, 08/11/1928. Disponível em: <http:// bndigital.bn.gov.br/hemeroteca-digital/>. Acesso em: abr. 2020.
} 
junho de $1932 .{ }^{28}{ }^{29}$ Ao longo dos anos de 1930, continuaram as escalas em São Francisco do Sul e Florianópolis.

Uma carta despachada no dia 01, em Florianópolis, pelos aviões da Condor, seguiria no mesmo dia em direção ao Rio de Janeiro. No dia seguinte, seria remetida ao porto da cidade, de onde partiria para a Europa via navegação. A previsão de chegada era para o dia 11 do mesmo mês. Portanto, em menos de duas semanas uma carta despachada em Florianópolis estaria no Velho Continente. Isso era uma revolução para os correios. ${ }^{30} \mathrm{Com}$ a entrada em operação da linha Berlim-Rio de Janeiro-Buenos Aires, em fevereiro de 1934, uma carta entre Florianópolis até a capital alemão levaria seis dias (Quadro 3). Os horários para as postagens eram os seguintes: para o Sul, às terças e sextas, as malas fechavam às $10 \mathrm{~h}$ para cartas registradas, e às $11 \mathrm{~h}$ para as simples; para o Norte, às segundas e quintas, às $16 \mathrm{~h}$ para as registradas, e às 20h para as simples. ${ }^{31}$

Em julho de 1935, com o aumento da frota (quatro novos Junkers Ju-52), foi ampliada para três voos semanais a linha Porto Alegre-Rio de Janeiro, com escalas em Florianópolis e São Francisco do Sul. Também foram ampliadas outras linhas em direção ao Norte e Interior do País. ${ }^{32}$ Com a abertura da linha até Santiago (com escalas em Montevidéu, Buenos Aires e Mendonza), em outubro de 1935, a Condor integrava a capital catarinense com todo o Cone Sul no transporte de cargas (mala postal) e passageiros ${ }^{33}$. No ano seguinte, já era possível viajar de Florianópolis até São Paulo e fazer uma conexão para La Paz, Arequipa e Lima pela aeronave Tibagy, um Junkers Ju-34. No Quadro 4 podemos acompanhar as rotas e os horários das malas postais despachadas a partir de Florianópolis para diversos destinos.

\footnotetext{
${ }^{28}$ O JORNAL. Serviço aéreo. Rio de Janeiro, 08/09/1931. Disponível em: <http://bndigital.bn.gov.br/hemeroteca-digital/>. Acesso em: abr. 2020.

${ }^{29}$ O JORNAL. Serviço aéreo. Rio de Janeiro, 15/06/1932. Disponível em: <http://bndigital.bn.gov.br/hemeroteca-digital/>. Acesso em: abr. 2020.

${ }^{30}$ REPÚBLICA. Syndicato Condor Ltda: mala para Europa pelo “Cap. Arcona”. Florianópolis, 01/02/1929. Disponível em: <http://bndigital.bn.gov.br/hemeroteca-digital/>. Acesso em: abr. 2020.

${ }^{31}$ O ESTADO. Correio aéreo. Florianópolis, 10/01/1933. Disponível em: <http://bndigital.bn.gov.br/hemeroteca-digital/>. Acesso em: abr. 2020.

${ }^{32}$ O ESTADO. Novo horário da "Condor": três voos por semana entre Rio e Porto Alegre. Florianópolis, 08/07/1935. Disponível em: <http://bndigital.bn.gov.br/hemeroteca-digital/>. Acesso em: abr. 2020.

${ }^{33}$ O ESTADO. A nova linha aérea sobre os Andes. Florianópolis, 15/10/1935. Disponível em: <http://bndigital. bn.gov.br/hemeroteca-digital/>. Acesso em: abr. 2020.
} 
Quadro 4: Rotas e horários das malas postais transportadas pela Syndicato Condor a partir de Florianópolis em 1935

\begin{tabular}{|c|c|c|}
\hline Rota & Escalas & Dia \\
\hline Para o Norte & $\begin{array}{l}\text { São Francisco do Sul, Paranaguá, } \\
\text { Santos, Rio de Janeiro, Vitória, } \\
\text { Caravelas, Belmonte, Ilhéus, } \\
\text { Salvador, Aracaju, Penedo, } \\
\text { Maceió, Recife, Cabedelo e Natal }\end{array}$ & $\begin{array}{c}\text { Todas as segundas: na } \\
\text { agência, às } 17 \mathrm{~h} \text {; no correio, } \\
\text { às 20h; e cartas registradas, } \\
\text { às } 18 \mathrm{~h}\end{array}$ \\
\hline $\begin{array}{l}\text { Para o Norte até } \\
\text { Natal e Europa }\end{array}$ & $\begin{array}{c}\text { Santos, Rio de Janeiro, Salvador } \\
\text { e Natal }\end{array}$ & $\begin{array}{c}\text { Todas as quintas: na agência, } \\
\text { às 9h30; no correio, às } 10 \mathrm{~h} \text {; e } \\
\text { cartas registradas, às } 9 \mathrm{~h}\end{array}$ \\
\hline $\begin{array}{l}\text { Para o Norte até } \\
\text { o Rio de Janeiro }\end{array}$ & $\begin{array}{c}\text { São Francisco do Sul, Paranaguá, } \\
\text { Santos, Rio de Janeiro; e via } \\
\text { Santos para Cuiabá }\end{array}$ & $\begin{array}{l}\text { Todas as sextas: na agência, } \\
\text { às } 17 \mathrm{~h} \text {; no correio, às } 20 \mathrm{~h} ; \mathrm{e} \\
\text { cartas registradas, às } 18 \mathrm{~h}\end{array}$ \\
\hline $\begin{array}{l}\text { Para o Sul até } \\
\text { Porto Alegre }\end{array}$ & Sem escala & $\begin{array}{l}\text { Todas as terças e sextas: } \\
\text { na agência, às } 10 \mathrm{~h} ; \text { no } \\
\text { correio, às 10h30; e cartas } \\
\text { registradas, às } 8 \text { h30 }\end{array}$ \\
\hline $\begin{array}{l}\text { Para o Sul até } \\
\text { Buenos Aires }\end{array}$ & $\begin{array}{c}\text { Porto Alegre, Montevidéu e } \\
\text { Buenos Aires }\end{array}$ & $\begin{array}{c}\text { Todos os sábados: na } \\
\text { agência, às } 12 \mathrm{~h} \text {. Todos os } \\
\text { domingos: no correio, às } \\
\text { 7h30; e cartas registradas, } \\
\text { às } 7 \text { h15 }\end{array}$ \\
\hline
\end{tabular}

Fonte: O ESTADO. Fechamento das malas aéreas Condor. Florianópolis, 09/07/1935. Disponível em: <http://bndigital.bn.gov.br/hemeroteca-digital/>. Acesso em: abr. 2020.

Em 1938, a Syndicato Condor, conforme notícia publicada no jornal "A Notícia", de 02 de novembro, previa suspender os pousos dos hidroaviões em São Francisco do Sul e estabelecer uma nova linha entre Curitiba e Florianópolis, com escala em Joinville..$^{34}$ Em outubro de 1940, foram estabelecidas novas escalas em Santa Catarina, com pousos em Joinville e Blumenau. Ambas as cidades já apresentavam características de cidade industrial: Joinville iniciando um processo de diversificação econômica fundada na indústria metalmecânica, e Blumenau consolidando-se na indústria têxtil e do vestuário. É bom lembrar que também eram duas cidades com descendência alemã e que naquele momento interessava muito ao III Reich manter contato com essas zonas de influência germânica. Lembramos que a rede elétrica

\footnotetext{
${ }^{34}$ A NOTíCIA. Aerolloyd Iguassu. Joinville, 02/11/1938. Disponível em: <http://bndigital.bn.gov.br/hemeroteca-digital/>. Acesso em: abr. 2020.
} 
da região norte catarinense era mantida pela Empresul, uma companhia de origem alemã. Para o Sul, até Porto Alegre, a escala ocorreria nas segundas e quartas para Florianópolis; para o Norte, até São Paulo e Rio de Janeiro, as escalas seriam nas terças e quintas. Em Joinville, o agente era Hermann Brosig, e em Blumenau, Carlos Hoepcke S.A.
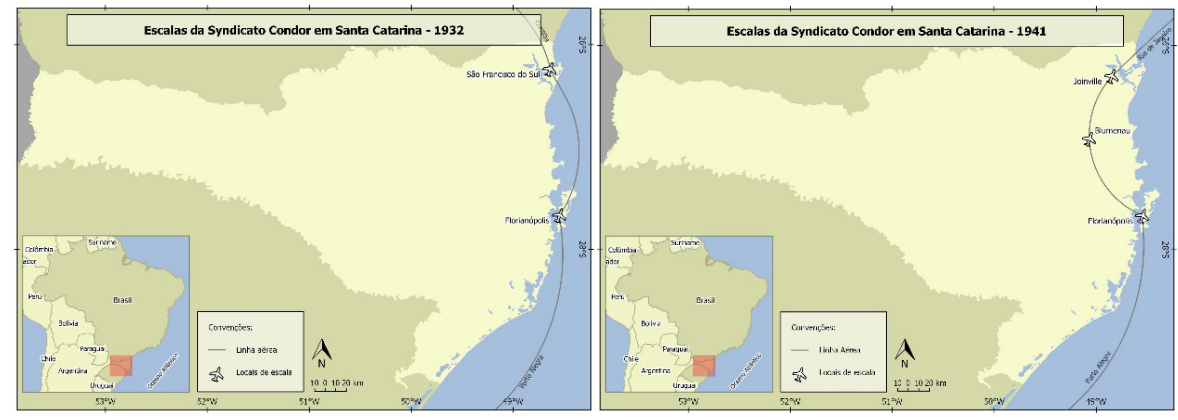

Após a completa nacionalização da tripulação, a restruturação dos horários e a mudança de nome para Serviços Aéreos Condor (ainda sob o controle da Lufthansa), a companhia passou a operar em duas cidades catarinense: Florianópolis e Blumenau. Com o reinício dos serviços regulares em 08 de abril de 1942, com um novo agente de Florianópolis, Machado \& Cia, tínhamos as seguintes partidas: para Porto Alegre, todas as terças; para Blumenau, Curitiba, São Paulo e Rio de Janeiro, todas as quartas..$^{35}$ Em outubro de 1943, agora como Serviços Aéreos Cruzeiro do Sul Ltda, foi retomada a escala em Joinville, mas, em seguida, com as complicações da guerra e o racionamento de combustível, a escala foi excluída da rota entre Curitiba e Florianópolis. Até o final da guerra, foi mantido em Santa Catarina apenas a escala em Florianópolis.

Com o fim da Segunda Guerra e a volta da normalidade do tráfego aéreo, a Cruzeiro do Sul já operava com um Douglas DC-3 e continuou com alguns Junkers Ju-52 e Focke Wulf 200 (26 passageiros). Em Santa Catarina, manteve uma única escala, na capital Florianópolis, com os seguintes horários: Direção Norte: Segundas, às $13 \mathrm{~h} 55$; terças, às $12 \mathrm{~h}$; quartas, às $11 \mathrm{~h}$; quintas, às $13 \mathrm{~h} 55$; sextas, às 7h20; sábados, às 13h55; e domingos, às 11h. Direção Sul: Quintas, às $15 \mathrm{~h} 300^{36}$

\footnotetext{
${ }^{35}$ O ESTADO. Propaganda dos Serviços Aéreos Condor. Florianópolis, 07/04/1942. Disponível em: <http:// bndigital.bn.gov.br/hemeroteca-digital/>. Acesso em: abr. 2020.

${ }^{36}$ O ESTADO. Viação aérea: horário. Florianópolis, 17/07/1948. Disponível em: <http://bndigital.bn.gov. br/hemeroteca-digital/>. Acesso em: abr. 2020.
} 
A Serviços Aéreos Cruzeiro do Sul continuou operando em Santa Catarina, inclusive para várias cidades do interior, durante as décadas seguintes, até ser incorporada pela VARIG, em 1975, e dissolvida em 1993.

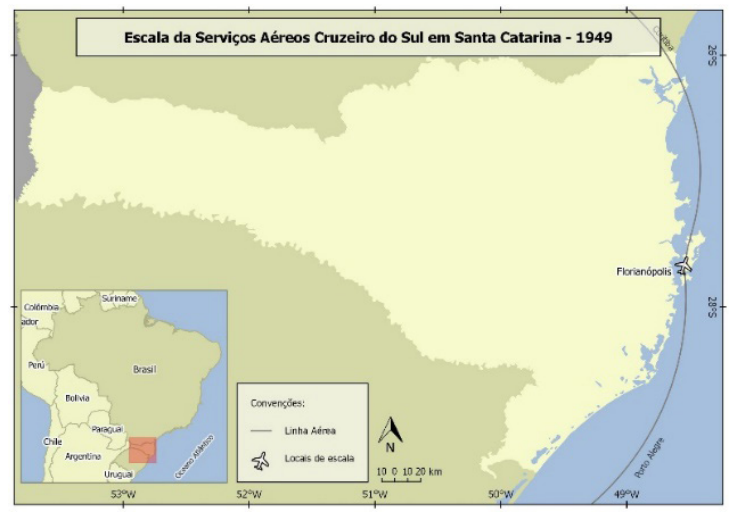

\section{NYRBA e Panair do Brasil}

\section{NYRBA no Brasil}

A New York Rio Buenos Aires Line (NYRBA) foi uma empresa norte-americana fundada no estado de Delaware, em 17 de março de 1929, tendo à frente o coronel Ralph O'Neill, cuja pretensão era estabelecer linhas aéreas entre New York, Miami, nos Estados Unidos, e diversas cidades sul-americanas.

Os primeiros quatro hidroaviões Consolidated Commodore, com capacidade para até 22 passageiros, para operarem no Brasil, chegaram em novembro de $1929^{37}$. Mesmo sem a autorização oficial para voar, a NYRBA inaugurou os serviços no Brasil - entre Rio de Janeiro e Buenos Aires, com paradas em Montevidéu, Rio Grande, Porto Alegre, Florianópolis e Santos - no dia 08 de janeiro de 1930, com a decolagem do hidroavião "Buenos Aires", que partiu da capital argentina. 0 tempo de viagem estava previsto para 33 horas e 30 minutos, sendo que 15 horas e 15 minutos seriam de voo, o restante do tempo seria nas cinco escalas. ${ }^{38}{ }^{39} \mathrm{Em}$ seguida, no dia 18 de janeiro, a linha foi esten-

\footnotetext{
${ }^{37}$ O JORNAL. A ligação aérea das Américas: os aparelhos da NYRBA em movimento para o sul. Rio de Janeiro, 15/11/1929. Disponível em: <http://bndigital.bn.gov.br/hemeroteca-digital/>. Acesso em: abr. 2020.

${ }^{38}$ O JORNAL. Capitão O’Neill. Rio de Janeiro, 08/01/1930. Disponível em: <http://bndigital.bn.gov.br/hemeroteca-digital/>. Acesso em: abr. 2020.

${ }^{39}$ O JORNAL. Buenos Aires-Rio de Janeiro: iniciada a linha aérea da NYRBA. Rio de Janeiro, 09/01/1930. Disponível em: <http://bndigital.bn.gov.br/hemeroteca-digital/>. Acesso em: abr. 2020.
} 
dida até a cidade de Santiago, no Chile..$^{40} \mathrm{~A}$ autorização para funcionamento da NYRBA foi emitida em seguida, por meio do Decreto $n^{\circ} 19.079^{41}$, de 24 de janeiro de 1930. No quadro abaixo, é possível visualizar os horários e as escalas da linha inaugural entre Rio de Janeiro e Buenos Aires.

Quadro 5: Horários e escalas da NYRBA do Brasil entre Rio de Janeiro e Buenos Aires em janeiro de 1930

\begin{tabular}{|c|c|c|c|c|c|c|}
\hline \multicolumn{4}{|c|}{ Sábado } & \multicolumn{4}{c|}{ Quarta feira } \\
\hline Saída & Rio de Janeiro & $7 \mathrm{~h}$ & Saída & Buenos Aires & $9 \mathrm{~h} 30$ \\
\hline Chegada & Santos & $9 \mathrm{~h} 15$ & Chegada & Montevidéu & $10 \mathrm{~h} 45$ \\
\hline Saída & Santos & $9 \mathrm{~h} 45$ & Saída & Montevidéu & $11 \mathrm{~h} 45$ \\
\hline Chegada & Florianópolis & $1 \mathrm{~h} 15$ & Chegada & Rio Grande & $3 \mathrm{~h}$ \\
\hline Saída & Florianópolis & $1 \mathrm{~h} 45$ & Saída & Rio Grande & $3 \mathrm{~h} 45$ \\
\hline Chegada & Porto Alegre & $4 \mathrm{~h} 45$ & Chegada & Porto Alegre & $5 \mathrm{~h} 30$ \\
\hline \multicolumn{5}{|c|}{ Domingo } & & \multicolumn{3}{|c|}{ Quinta-feira } \\
\hline Saída & Porto Alegre & $9 \mathrm{~h} 15$ & Saída & Porto Alegre & $7 \mathrm{~h}$ \\
\hline Chegada & Rio Grande & $10 \mathrm{~h} 30$ & Chegada & Florianópolis & $10 \mathrm{~h} 45$ \\
\hline Saída & Rio Grande & $11 \mathrm{~h} 15$ & Saída & Florianópolis & $10 \mathrm{~h} 30$ \\
\hline Chegada & Montevidéu & $15 \mathrm{~h}$ & Chegada & Santos & $14 \mathrm{~h}$ \\
\hline Saída & Montevidéu & $15 \mathrm{~h} 15$ & Saída & Santos & $14 \mathrm{~h} 30$ \\
\hline Chegada & Buenos Aires & $16 \mathrm{~h} 30$ & Chegada & Rio de Janeiro & $4 \mathrm{~h} 45$ \\
\hline
\end{tabular}

Fonte: REPÚBLICA. Anúncio da NYRBA do Brasil SA. Florianópolis, 08/01/1930. Disponível em: <http://bndigital.bn.gov.br/hemeroteca-digital/>. Acesso em: abr. 2020.

A linha norte entrou em operação em 24 de janeiro, partindo da capital brasileira o hidroavião "Porto Alegre", que fazia escalas em Campos, Vitória, Ilhéus, Aracaju, Maceió, Recife e Natal. ${ }^{42}$ Essa mesma rota, depois, continuava em direção a Belém para, em seguida, partir para os Estados Unidos, com diversas escalas no Caribe. Na América do Sul, a NYRBA operava com uma frota de 14 aeronaves do tipo Consolidated Commodore.43

\footnotetext{
${ }^{40}$ O JORNAL. Vias aéreas pan-americana. Rio de Janeiro, 17/01/1930. Disponível em: <http://bndigital.bn.gov. br/hemeroteca-digital/>. Acesso em: abr. 2020.

${ }^{41}$ BRASIL. Decreto $n^{2} 19.079$, de 24 de janeiro de 1930. Brasília: Câmara dos Deputados. Disponível em: <https:// www2.camara.leg.br/atividade-legislativa/legislacao>. Acesso em: março/2020.

${ }^{42}$ O JORNAL. Linha aérea de passageiros do Rio ao Ceará. Rio de Janeiro, 24/01/1930. Disponível em: <http:// bndigital.bn.gov.br/hemeroteca-digital/>. Acesso em: abr. 2020.

${ }^{43}$ O JORNAL. Chegou ontem mais um avião da NYRBA. Rio de Janeiro, 14/01/1930. Disponível em: <http:// bndigital.bn.gov.br/hemeroteca-digital/>. Acesso em: abr. 2020.
} 
Porém, com a Grande Depressão do início dos anos de 1930, causada pela desastrosa quebra da Bolsa de Valores de New York, em 1929, a NYRBA enfrentou diversas dificuldades financeiras. Para evitar a falência da empresa, a Pan American Airways, em agosto de 1930, adquiriu a maioria das ações e assumiu o controle da empresa. A Pan American, fundada em 1927, já era uma sólida companhia aérea que operava nos Estados Unidos ligando a costa Leste à Oeste, além de voos no Pacífico. No Brasil a NYRBA, também controlada pela Pan American, passou a chamar-se Pan Air do Brasil S.A. ou, como ficou mais conhecida, Panair. ${ }^{44}$ O Decreto $n^{\circ} 19.417,{ }^{45}$ de 21 de novembro de 1930, reconheceu a nova denominação da empresa e manteve todas as concessões do Decreto $\mathrm{n}^{\circ} 19.079,{ }^{46}$ de 24 de janeiro.

A Panair continuou operando como multinacional no Brasil até 1961, quando foi adquirida por empresários brasileiros. Em fevereiro de 1965, respaldado pela ditadura, inesperadamente, o Ministério da Aeronáutica caçou sua licença de voo e, em seguida, foi decretada a sua falência, mesmo apresentando solvência financeira.

\section{NYRBA e Panair em Santa Catarina}

Santa Catarina entrou na rota da NYRBA, com escala em Florianópolis, no caminho de Porto Alegre, ao Sul, e de Santos, ao Norte. As escalas, de aproximadamente 30 minutos, estavam previstas, para o Norte, todas as quintas, às 10h. Para o Sul, aos sábados, às 13h15. A Syriaco T. Atherino \& Irmão, localizada na Rua Conselheiro Mafra, era o agente autorizado a realizar as operações da NYRBA em Florianópolis. ${ }^{47}$ No voo inaugural entre Buenos Aires ao Rio de Janeiro, o hidroavião Buenos Aires aterrissou em Florianópolis no dia 09 de janeiro, às $10 \mathrm{~h}$ da manhã, conforme previsto. Na capital catarinense, realizou o abastecimento com gasolina da Standard, fornecida pelo agente Syriaco T. Atherino \& Irmão. Não houve embarque ou desembarque de passageiros. ${ }^{48}$

\footnotetext{
${ }^{44}$ O JORNAL. Anúncio Pan American Airways. Rio de Janeiro, 04/11/1930. Disponível em: <http://bndigital. bn.gov.br/hemeroteca-digital/>. Acesso em: abr. 2020.

${ }^{45}$ BRASIL. Decreto nº 19.417, de 21 de novembro de 1930. Brasília: Câmara dos Deputados. Disponível em: <https://www2.camara.leg.br/atividade-legislativa/legislacao>. Acesso em: março/2020.

${ }^{46}$ BRASIL. Decreto $n^{2} 19.079$, de 24 de janeiro de 1930. Brasília: Câmara dos Deputados. Disponível em: <https:// www2.camara.leg.br/atividade-legislativa/legislacao>. Acesso em: março/2020.

${ }^{47}$ REPÚBLICA. Hidroavião “Buenos Aires”. Florianópolis, 11/01/1930. Disponível em: <http://bndigital.bn.gov. br/hemeroteca-digital/>. Acesso em: abr. 2020.

${ }^{48}$ REPÚBLICA. Hidroavião "Buenos Aires". Florianópolis, 10/01/1930. Disponível em: <http://bndigital.bn.gov. br/hemeroteca-digital/>. Acesso em: abr. 2020.
} 
Porém, nas escalas seguintes, havia a movimentação de passageiros provenientes de Porto Alegre ou que seguiam para o Rio de Janeiro. A NYRBA também tinha a autorização para fazer o transporte das malas postais, as quais também eram embarcadas e desembarcadas em Florianópolis.

Em março, houve uma alteração no horário na escala em Florianópolis, na direção Norte para o Sul, para o transporte de malas postais e passageiros, com aterrissagem na baía Sul prevista para as sextas, às $12 \mathrm{~h}$. Nas propagandas divulgas nos jornais República e O Estado, da Syriaco T. Atherino \& Irmão, havia a seguinte informação: "Linhas regulares duas vezes por semana. Acomodações luxuosas". Como estratégia de concorrência, a NYRBA se colocava como uma empresa que prestava serviços de alta qualidade em hidroaviões luxuosos, confortáveis e serviço de bordo, como eram os Consolidated Commodore.
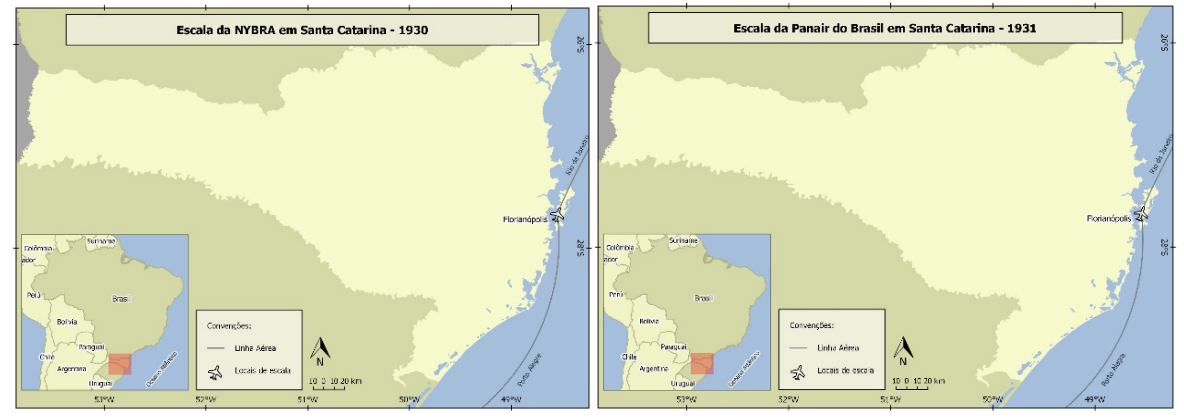

Com a incorporação da Pan American, a Panair do Brasil encerrou a linha para o Sul, que incluía Buenos Aires. Manteve apenas a cidade de Santos. Os voos para o Sul foram retomados em 02 de novembro de 1931, com escalas, além de Santos, em Paranaguá, Florianópolis, Porto Alegre, Rio Grande, Montevidéu e Buenos Aires. ${ }^{49}$ Nos anos seguintes, houve somente alterações nos horários, sem nenhuma ampliação da linha, nem novas escalas em Santa Catarina. Em 1931, continuou com uma escala nas segundas para o Norte e o Sul, às 9 h e às $12 \mathrm{~h}$, respectivamente. Em 1935, as escalas na capital catarinense eram realizadas nas quartas; em 1936, rumo ao Sul, passaram para as terças, e

${ }_{49}$ O JORNAL. Serviço aéreo. Rio de Janeiro, 28/10/1931. Disponível em: <http://bndigital.bn.gov.br/hemeroteca-digital/>. Acesso em: abr. 2020. 
ao Norte, para as quintas. ${ }^{50}{ }^{51} \mathrm{~A}$ partir de 1937, a Panair começou a incorporar na sua frota os Lockheed A/E 10 Electra, desfazendo-se dos seus hidroaviões.

Nos anos de 1940, com a modernização constante da frota, sobretudo com as aquisições dos Douglas DC-3 e Lockheed Constellation, e com a expansão de novas rotas no Brasil, em janeiro de 1941, a Panair ampliou as escalas em Florianópolis: para a rota Sul, às terças, quintas e aos domingos; para o Norte, às segundas, quartas e sextas.$^{52}$ Em julho de 1944 , foi incluída mais uma escala em Florianópolis, ligando a cidade de Curitiba à capital catarinense..$^{53}$ No ano seguinte, com as restrições da guerra, as escalas em Florianópolis reduziram-se para as quartas e os sábados (rumo ao Sul) e quintas e domingos (rumo Norte), mantendo a escala em Curitiba. ${ }^{54} \mathrm{Em} \mathrm{1946,} \mathrm{foram} \mathrm{mantidas} \mathrm{as}$ duas escalas, com alteração apenas nos dias: com destino a Porto Alegre, às segundas e aos sábados, e para Curitiba, São Paulo e Rio de Janeiro, às segundas e aos domingos. ${ }^{55} \mathrm{Em} \mathrm{1947}$, às duas rotas foram incluídas mais duas escalas. ${ }^{56}$ No final da década, a Panair do Brasil já era a maior companhia aérea brasileira, com diversos destinos nacionais e internacionais, e fazia escalas diárias em Florianópolis.

\section{Aerolloyd Iguassu e Viação Aérea São Paulo (VASP)}

A Aerolloyd Iguassu foi uma companhia aérea paranaense fundada em 28 de setembro de 1932, na cidade de Curitiba, tendo como presidente Ivo de Abreu Leão (proprietário do Leão Júnior \& Cia - Mate Leão). O objetivo da companhia era estabelecer uma linha aérea entre Joinville, Curitiba e São Paulo, com possível expansão da rota para outras cidades catarinenses..$^{57} \mathrm{Um}$

${ }^{50}$ REPÚBLICA. Fechamento das malas aéreas no Correio. Florianópolis, 04/06/1935. Disponível em: <http:// bndigital.bn.gov.br/hemeroteca-digital/>. Acesso em: abr. 2020.

${ }^{51}$ REPÚBLICA. Panair do Brasil: mudança de horário. Florianópolis, 07/11/1936. Disponível em: <http:// bndigital.bn.gov.br/hemeroteca-digital/>. Acesso em: abr. 2020.

${ }^{52}$ O ESTADO. Anúncio da Panair do Brasil SA. Florianópolis, 31/12/1940. Disponível em: <http://bndigital. bn.gov.br/hemeroteca-digital/>. Acesso em: abr. 2020.

${ }^{53}$ O ESTADO. As viagens da Panair. Florianópolis, 31/07/1944. Disponível em: <http://bndigital.bn.gov.br/ hemeroteca-digital/>. Acesso em: abr. 2020.

${ }^{54}$ O ESTADO. Aviões Panair. Florianópolis, 23/07/1945. Disponível em: <http://bndigital.bn.gov.br/hemeroteca-digital/>. Acesso em: abr. 2020.

${ }^{55}$ O ESTADO. Viação aérea: horário. Florianópolis, 23/01/1946. Disponível em: <http://bndigital.bn.gov. br/hemeroteca-digital/>. Acesso em: abr. 2020.

${ }^{56}$ O ESTADO. Anúncio da Panair do Brasil SA. Florianópolis, 24/08/1947. Disponível em: <http://bndigital. bn.gov.br/hemeroteca-digital/>. Acesso em: abr. 2020.

${ }^{57}$ DIÁRIO DA TARDE. Foi fundada em Curitiba uma empresa de aviação. Curitiba, 30/09/1932. Disponível em: $<$ http://bndigital.bn.gov.br/hemeroteca-digital/>. Acesso em: abr. 2020. 
pouco antes, em maio de 1932, foi realizado um raid entre Blumenau e São Paulo pelo aviador Sidney Hary Holland, pilotando um Moth, contratado pela Leão Júnior \& Cia, para estudar a rota da futura companhia aérea) ${ }^{58}$

Autorizada a funcionar por meio do Decreto $n^{\circ} 22.878$, de 30 de junho de 1933, a Aerolloyd Iguassu iniciou suas operações no dia 18 de julho de 1933, no voo inaugural entre São Paulo e Curitiba. ${ }^{59} \mathrm{Na}$ sequência, o voo seguiu até Blumenau e Joinville. No início, a empresa operava com duas aeronaves Klemm K1 31A, com capacidade para três passageiros; depois, em outubro de 1934, foram acrescidos mais três monomotores Stinson Reliant, para quatro passageiros. A tabela de horários, que também incluía as malas postais, era a seguinte: a linha São Paulo-Curitiba, às $12 \mathrm{~h} 30$, nas terças, quartas, quintas e sextas; a linha Curitiba-Blumenau-Joinville, às 12h30, nas quartas e sextas.

Para estender os voos para outras cidades de Santa Catarina, a Aerolloyd solicitou ao governo catarinense, em julho de 1934, uma subvenção de $1 \$ 000$ por quilômetro voado, além de um apoio financeiro de 100:000\$000 para a construção de uma base aérea própria. ${ }^{60}$ Atendendo ao pedido da Aerolloyd, o governo catarinense liberou um crédito de 40:000\$000 e um auxílio mensal de 2:000 $\$ 000$, que estavam abaixo do esperado. ${ }^{61}$ Em resposta, a Aerolloyd estendeu seus voos para Florianópolis, que começaram no dia 15 de janeiro de 1935, e Itajaí, em 19 de março de 1935. A empresa prometia ampliá-los até o sul do Estado, com escalas em Laguna e Tubarão. No entanto, o governo catarinense, sob o comando do lageano Nereu Ramos, almejava que os voos seguissem até a cidade de Lages. ${ }^{62}$ Como o litoral catarinense já estava sendo atendido pela Syndicato Condor e pela Panair do Brasil, além da Aéropostale, era intenção do governo catarinense levar os serviços aéreos para o planalto serrano, iniciando um processo de integração aérea do território catarinense.

O governo do Paraná, por meio do Decreto no 744 , de 07 de maio de 1935, concedeu à Aerolloyd uma subvenção de 50:000\$000. ${ }^{63}$ Mesmo assim,

\footnotetext{
${ }^{58}$ O DIA. Asas ao Paraná: raid S. Paulo-Blumenau. Curitiba, 05/05/1932. Disponível em: <http://bndigital. bn.gov.br/hemeroteca-digital/>. Acesso em: abr. 2020.

${ }^{59}$ DIÁRIO DA TARDE. O voo inaugural da “Aerolloyd Iguassu SA". Curitiba, 18/07/1933. Disponível em: <http:// bndigital.bn.gov.br/hemeroteca-digital/>. Acesso em: abr. 2020.

${ }^{60}$ O ESTADO. De cima para baixo. Florianópolis, 13/07/1934. Disponível em: <http://bndigital.bn.gov.br/ hemeroteca-digital/>. Acesso em: abr. 2020.

${ }^{61}$ O ESTADO. 40 contos para Aerolloyd. Florianópolis, 02/08/1934. Disponível em: <http://bndigital.bn.gov. br/hemeroteca-digital/>. Acesso em: abr. 2020.

${ }^{62}$ A NOTíCIA. O governo e a Aerolloyd Iguassu: essa companhia suspendeu os voos a Santa Catarina. Joinville, 17/01/1936. Disponível em: <http://bndigital.bn.gov.br/hemeroteca-digital/>. Acesso em: abr. 2020.

${ }^{63}$ O DIA. Atos governamentais: Decreto n. 744. Curitiba, 08/05/1935. Disponível em: <http://bndigital.bn.gov. br/hemeroteca-digital/>. Acesso em: abr. 2020.
} 
a empresa solicitava constantemente novas subvenções para os governos catarinense e paranaense, alegando que a Viação Aérea de São Paulo (VASP) tinha mais capacidade de realizar voos devido aos benefícios financeiros recebidos do governo paulista. ${ }^{64}$
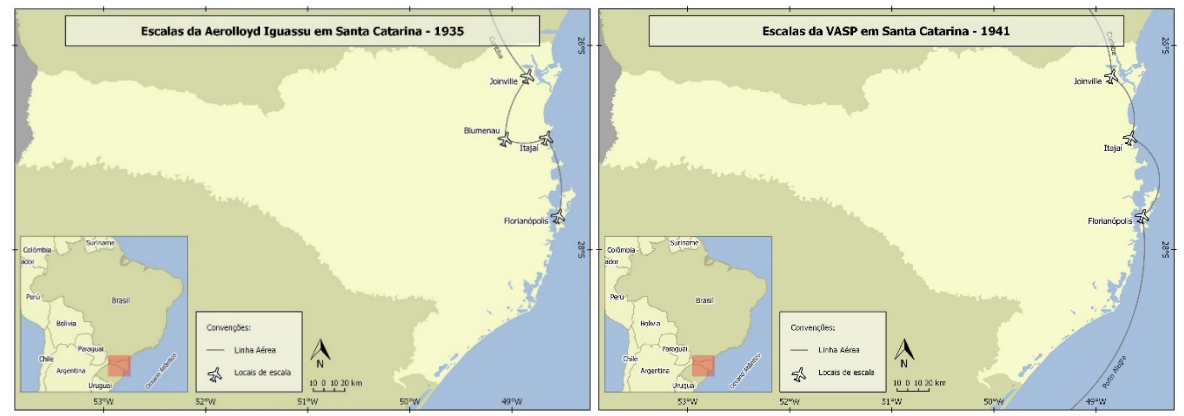

Como a Aerolloyd se negava a estender sua linha até Lages, o governador Nereu Ramos não liberou os subsídios requeridos. Em resposta, em janeiro de 1936, a empresa suspendeu os voos para Santa Catarina.$^{65}$ A Aerolloyd Iguassu voltaria a realizar voos para Santa Catarina, com escalas em Joinville, Itajaí e Florianópolis, em março de 1937, quando foi sinalizado pelo Senado Federal que seria aprovada uma nova subvenção. ${ }^{66}$ Por fim, após a persistência e a pressão política da Leão Júnior \& Cia, a Lei nำ 468, de 31 de julho de 1937, autorizou o poder executivo a contratar a companhia para realizar voos entre São Paulo, Curitiba e Florianópolis, por meio de uma subvenção de $2 \$ 000$ por quilômetros voados, limitada a uma despesa anual de 240:000\$000. Para completar ainda mais as subvenções, a Prefeitura Municipal de Joinville, no orçamento de 1937, aprovou um auxílio mensal de 6:000\$000. ${ }^{67}$

Em setembro de 1938, a Aerolloyd assinou um acordo com a VASP para atuarem juntas na combinação dos voos entre Curitiba e São Paulo, com

\footnotetext{
${ }^{64}$ A NOTíCIA. A Aerolloyd e o apelo ao governo do Estado. Joinville, 21/03/1936. Disponível em: <http:// bndigital.bn.gov.br/hemeroteca-digital/>. Acesso em: abr. 2020.

${ }^{65}$ A NOTíCIA. O governo e a Aerolloyd Iguassu: essa companhia suspendeu os voos a Santa Catarina. Joinville, 17/01/1936. Disponível em: <http://bndigital.bn.gov.br/hemeroteca-digital/>. Acesso em: abr. 2020.

${ }^{66}$ A NOTícIA. A Aerolloyd Iguassu reiniciará suas atividades. Joinville, 25/03/1937. Disponível em: <http:// bndigital.bn.gov.br/hemeroteca-digital/>. Acesso em: abr. 2020.

${ }^{67}$ A GAZETA. Prefeitura Municipal de Joinville. Florianópolis, 29/03/1938. Disponível em: <http://bndigital. bn.gov.br/hemeroteca-digital/>. Acesso em: abr. 2020.
} 
conexão para o Rio de Janeiro (Quadro 7). ${ }^{68}{ }^{69}$ Eram duas empresas que estavam vivendo momentos diferentes: a Aerolloyd não conseguia ampliar sua frota e dependia de subvenções e de auxílios financeiros do Estado, e a VASP, recém-estatizada pelo governo paulista, estava com planos de ampliação. No ano seguinte, por meio do Decreto no $4.812,{ }^{70}$ de 28 de outubro de 1939, foi autorizado à Aerolloyd transferir as linhas de Florianópolis a São Paulo, com escala em Curitiba, para a VASP. Por fim, no mês seguinte, a companhia paranaense foi adquirida pela estatal paulista.

Quadro 7: Horários conjugados da Aerolloyd Iguassu e a VASP na linha São Paulo a Florianópolis em 1938

\begin{tabular}{|c|c|c|c|c|c|}
\hline Dia & Companhia & Partida & Hora & Chegada & Hora \\
\hline Segunda & VASP & São Paulo & $11 \mathrm{~h} 30$ & Curitiba & $13 \mathrm{~h}$ \\
\hline Terça & VASP & Curitiba & $11 \mathrm{~h} 30$ & São Paulo & $12 \mathrm{~h} 30$ \\
\hline Quarta & VASP & Curitiba & $11 \mathrm{~h} 30$ & São Paulo & $13 \mathrm{~h} 15$ \\
\hline Quinta & Aerolloyd & São Paulo & $11 \mathrm{~h} 30$ & Curitiba & $13 \mathrm{~h} 45$ \\
\hline Quinta & Aerolloyd & Curitiba & $14 \mathrm{~h}$ & Joinville & $14 \mathrm{~h} 45$ \\
\hline Quinta & Aerolloyd & Joinville & $15 \mathrm{~h}$ & Itajaí & $15 \mathrm{~h} 30$ \\
\hline Quinta & Aerolloyd & Itajaí & $15 \mathrm{~h} 30$ & Florianópolis & $16 \mathrm{~h}$ \\
\hline Sexta & Aerolloyd & Florianópolis & $8 \mathrm{~h} 30$ & Itajaí & $9 \mathrm{~h}$ \\
\hline Sexta & Aerolloyd & Itajaí & $9 \mathrm{~h}$ & Joinville & $9 \mathrm{~h} 30$ \\
\hline Sexta & Aerolloyd & Joinville & $9 \mathrm{~h} 45$ & Curitiba & $10 \mathrm{~h} 30$ \\
\hline Sexta & Aerolloyd & Curitiba & $11 \mathrm{~h}$ & São Paulo & $13 \mathrm{~h} 15$ \\
\hline Sábado & Aerolloyd & São Paulo & $11 \mathrm{~h}$ & Curitiba & $13 \mathrm{~h} 45$ \\
\hline
\end{tabular}

Fonte: A NOTíCIA. Aerolloyd Iguassu. Joinville, 02/11/1938. Disponível em: <http://bndigital. bn.gov.br/hemeroteca-digital/>. Acesso em: abr. 2020.

A VASP começou suas operações em 12 de novembro de 1933, com a decolagem de dois bimotores Monospar ST-4, com destino a Rio Preto e escala

\footnotetext{
${ }^{68}$ TRIBUNA DO COMÉRCIO. A Aerolloyd e a VASP assinaram um acordo para o serviço comercial Curitiba-São Paulo-Rio. Curitiba, 22/09/1938. Disponível em:<http://bndigital.bn.gov.br/hemeroteca-digital/>. Acesso em: abril/2020.

${ }^{69}$ A NOTÍCIA. A intensificação e o melhoramento do transporte aéreo entre São Paulo-Paraná-Santa Catarina em conexão com o Rio de Janeiro. Joinville, 07/10/1938. Disponível em: <http://bndigital.bn.gov.br/hemeroteca-digital/>. Acesso em: abr. 2020.

${ }^{70}$ Decreto $n^{\circ} 4.812$, de 28 de outubro de 1939. Brasília: Câmara dos Deputados. Disponível em: <https://www2. camara.leg.br/atividade-legislativa/legislacao>. Acesso em: março/2020.
} 
em São Carlos, e Uberaba, com escalas em Ribeirão Preto e Franca. ${ }^{71}$ Porém, devido às dificuldades operacionais, os voos foram cancelados e a linha suspensa. Em 31 de março de 1934, foi aprovado o Decreto $n^{\circ} 20.070,{ }^{72}$ que concedeu permissão para a VASP estabelecer tráfego aéreo em todo o território nacional. As operações retomaram em 15 de abril de 1934, quando se realizou oficialmente a solenidade de inauguração da VASP. ${ }^{73} \mathrm{Na}$ oportunidade, a VASP apresentou sua frota, que era composta por três aviões, com destaque para o bimotor Havilland DH 84 Dragon, com capacidade para 10 passageiros, que foi batizado com o nome de VASP $3 .^{74}$ Logo após o reinício das suas atividades, a Prefeitura Municipal de São Paulo garantiu uma subvenção de 400:000\$000. ${ }^{75}$

Com apenas um ano operando, a VASP recorreu ao governo estadual para solicitar auxílio financeiro e subvenção por quilômetro voado, porém o que ocorreu foi uma estatização da companhia. O Decreto Estadual no 7.308, ${ }^{76}$ de 05 de julho de 1935, garantiu uma subvenção anual de 500:000\$000. Não sendo suficiente, em dezembro do mesmo ano, o Decreto Estadual nº $7.493^{77}$ abriu um crédito especial para a companhia no valor de 12:000\$000. Por fim, a Lei Estadual $n^{0} 2.561,^{78}$ de 13 de janeiro de 1936, permitiu ao governo paulista fazer um aporte de capital no valor de 1.000:000\$000, o que significou o controle acionário da VASP. Nos anos seguintes, até 1939, o governo paulista aprovou seguidamente novas linhas de crédito para a VASP ampliar sua frota e saldar seus débitos. Foi nesse momento de expansão que as linhas da Aerolloyd Iguassu foram transferidas para a VASP, em outubro de 1939.

Não houve paralização dos voos para Santa Catarina após a compra da Aerolloyd, mas sim a troca das pequenas aeronaves, Klemm e Stinson Reliant, por

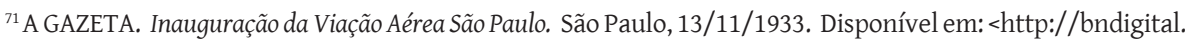
bn.gov.br/hemeroteca-digital/>. Acesso em: abr. 2020.

${ }^{72}$ BRASIL. Decreto n²0.070, de 31 de março de 1934. Brasília: Câmara dos Deputados. Disponível em: <https:// www2.camara.leg.br/atividade-legislativa/legislacao>. Acesso em: março/2020.

${ }^{73}$ CORREIO DE S. PAULO. Completou um ano de atividade a Viação Aérea São Paulo. São Paulo, 16/04/1935. Disponível em: <http://bndigital.bn.gov.br/hemeroteca-digital/>. Acesso em: abr. 2020.

${ }^{74}$ PILEGGI, Aristides. VASP: seus dez primeiros anos de vida. In: Revista do Instituto Histórico e Geográfico de São Paulo. São Paulo: IHGSP, v. LXXVIII, p. 323-362, 1982.

${ }^{75}$ CORREIO DE S. PAULO. Completou um ano de atividade a Viação Aérea São Paulo. São Paulo, 16/04/1935. Disponível em: <http://bndigital.bn.gov.br/hemeroteca-digital/>. Acesso em: abr. 2020.

${ }^{76}$ SÃO PAULO. Decreto Estadual n 7.308, de 05 de julho de 1935. São Paulo: Assembleia Legislativa. Disponível em: <https://www.al.sp.gov.br/alesp/pesquisa-legislacao/> Acesso em: março/2020

${ }^{77}$ SÃO PAULO. Decreto Estadual n 7.493, de 30 de dezembro de 1935. São Paulo: Assembleia Legislativa. Disponível em: <https://www.al.sp.gov.br/alesp/pesquisa-legislacao/> Acesso em: março/2020.

${ }^{78}$ SÃO PAULO. Lei Estadual no 2.561, de 13 de janeiro de 1936. São Paulo: Assembleia Legislativa. Disponível em: <https://www.al.sp.gov.br/alesp/pesquisa-legislacao/> Acesso em: março/2020.
} 
maiores, Junkers Ju-52. Inicialmente, foram mantidas as escalas em Joinville, Itajaí e Florianópolis, com a supressão de Blumenau. No dia 30 de novembro, pousou o primeiro avião da VASP em Florianópolis. ${ }^{79} \mathrm{~A}$ VASP também manteve o serviço postal aéreo entre Curitiba e São Paulo, mas estabeleceu um acordo com a Auto Viação Catarinense, que transportava as malas postais de ônibus de Joinville a Curitiba, seguindo, depois, de avião até São Paulo e Rio de Janeiro. ${ }^{80}$ No Quadro 9, podemos observar os horários da VASP na linha Rio de Janeiro a Porto Alegre, com escalas nas cidades de São Paulo, Curitiba, Joinville, Itajaí e Florianópolis.

Quadro 9: Horários e escalas da VASP na linha Rio de Janeiro a Porto Alegre em 1941

\begin{tabular}{|c|c|c|c|c|c|}
\hline \multicolumn{2}{|c|}{ Ida (Quinta-feira) } & \multicolumn{3}{c|}{ Volta (Sexta-feira) } \\
\hline Escala & Chegada & Partida & Escala & Chegada & Partida \\
\hline São Paulo & & $10 \mathrm{~h}$ & Porto Alegre & & $7 \mathrm{~h} 30$ \\
\hline Curitiba & $11 \mathrm{~h} 30$ & $12 \mathrm{~h}$ & Florianópolis & $9 \mathrm{~h} 20$ & $9 \mathrm{~h} 30$ \\
\hline Joinville & $12 \mathrm{~h} 25$ & $12 \mathrm{~h} 30$ & Itajaí & $9 \mathrm{~h} 55$ & $10 \mathrm{~h}$ \\
\hline Itajaí & $12 \mathrm{~h} 50$ & $13 \mathrm{~h}$ & Joinville & $10 \mathrm{~h} 20$ & $10 \mathrm{~h} 30$ \\
\hline Florianópolis & $13 \mathrm{~h} 24$ & $13 \mathrm{~h} 25$ & Curitiba & $10 \mathrm{~h} 55$ & $11 \mathrm{~h} 25$ \\
\hline Porto Alegre & $15 \mathrm{~h} 25$ & & São Paulo & $12 \mathrm{~h} 55$ & \\
\hline
\end{tabular}

Fonte: O ESTADO. Anúncio de horários da VASP. Florianópolis, 04/01/1941. Disponível em: <http://bndigital.bn.gov.br/hemeroteca-digital/>. Acesso em: abr. 2020.

Dentro das estratégias da VASP de ampliar a ligação de São Paulo com as capitais brasileiras, no dia 14 de novembro de 1940, foi aberta a linha até Porto Alegre, com escalas em Santa Catarina, nas cidades de Joinville, Itajaí e Florianópolis. Porém, com a declaração de guerra em agosto de 1942, a VASP cancelou todos os seus voos para Santa Catarina e Rio Grande do Sul. Ela retornou a Santa Catarina em junho de $1964 .^{81}$

\section{Viação Aérea Rio-Grandense (VARIG)}

A Viação Aérea Rio-Grandense (VARIG) foi fundada em 1927, na cidade de Porto Alegre, e tornou-se na maior companhia aérea do Brasil e da América

${ }^{79}$ O ESTADO. Inaugura-se a linha aérea VASP. Florianópolis, 01/12/1939. Disponível em: <http://bndigital. bn.gov.br/hemeroteca-digital/>. Acesso em: abr. 2020.

${ }^{80}$ A NOTÍ́CIA. Joinville vai servir-se do correio aéreo da VASP. Joinville, 25/08/1940. Disponível em: <http:// bndigital.bn.gov.br/hemeroteca-digital/>. Acesso em: abr. 2020.

${ }^{81}$ O ESTADO. Comitiva da VAPS visitou o governador. Florianópolis, 19/06/1964. Disponível em: <http:// bndigital.bn.gov.br/hemeroteca-digital/>. Acesso em: abr. 2020. 
Latina entre os anos de 1960 e 1990. Adquiriu a Real Transportes Aéreos, em 1961; beneficiou-se da falência forçada da Panair, em 1965; e comprou a Cruzeiro do Sul, em 1975. Sua história, nos estudos sobre aviação comercial, é amplamente conhecida por meio de diversas publicações, portanto, destacaremos apenas o início das suas operações em Santa Catarina.

Os serviços da VARIG foram inaugurados no Estado no dia 14 de janeiro de 1946, quando a aeronave Lockheed Electra, com capacidade para 10 passageiros, aterrissou, às 13h, na Base Aérea de Florianópolis, onde foi recepcionada por autoridades locais e estaduais.$^{82}$ Essa escala em Florianópolis fazia parte da rota Porto Alegre a Curitiba, que depois foi estendida até Montevidéu, com escalas em Pelotas e Jaguarão, passando a operar com um Douglas DC-3. Os horários eram os seguintes:

Quadro 10: Horários e escalas da VARIG entre Porto Alegre e Curitiba em 1946

\begin{tabular}{|c|c|c|}
\hline Linha & Dia & Horário \\
\hline Porto Alegre - Florianópolis - Curitiba & Quintas e domingos & $14 \mathrm{~h} 15$ \\
\hline Curitiba - Florianópolis - Porto Alegre & Segundas e sextas & $10 \mathrm{~h}$ \\
\hline
\end{tabular}

Fonte: O ESTADO. Propaganda da VARIG. Florianópolis, 17/08/1946. Disponível em: <http:// bndigital.bn.gov.br/hemeroteca-digital/>. Acesso em: abr. 2020.

Em Florianópolis, a VARIG tinha agência própria, que se localizava no Edifício Hotel La Porta, no centro da cidade. No ano seguinte, em 1947, a rota completa foi entre Rio de Janeiro e Montevidéu, com escalas em São Paulo, Curitiba, Florianópolis e Porto Alegre.$^{83} \mathrm{Em}$ setembro de 1947, havia voos de segunda a sexta: segunda, quarta e sexta rumo ao Norte (Rio de Janeiro); e terça e quinta, ao Sul (Porto Alegre e Montevidéu). No mês seguinte, também foi incluído o sábado na rota para o Sul.

A Portaria nº 140, de 20 de maio de 1949, da Diretoria Geral de Aviação Civil (DAC), autorizou escalas em Araranguá e Joinville na linha regular entre Porto Alegre a Rio de Janeiro. ${ }^{84}$ A escala em Araranguá representava estar próximo ao complexo carbonífero, onde havia unidades da Companhia Siderúrgica Nacional (CSN) em Criciúma e Siderópolis. As escalas eram

\footnotetext{
${ }_{82}$ O ESTADO. Inaugurado o serviço aéreo VARIG, nesta capital. Florianópolis, 15/01/1946. Disponível em: <http:// bndigital.bn.gov.br/hemeroteca-digital/>. Acesso em: abr. 2020.

${ }^{83}$ O ESTADO. Propaganda da VARIG. Florianópolis, 04/02/1947. Disponível em: <http://bndigital.bn.gov.br/ hemeroteca-digital/>. Acesso em: abr. 2020.

${ }^{84}$ DIÁRIO OFICIAL DA UNIÃO. Portaria n. 104, de 20 de maio de 1949. Rio de Janeiro: Imprensa Oficial, 30/05/1949. Disponível em: <https://www.jusbrasil.com.br/diarios/DOU/1949/05/30>. Acesso em: abr. 2020.
} 
realizadas três vezes por semana, nas terças, quintas e sábados ${ }^{85}$ Por fim, a Portaria n 340, ${ }^{86}$ de 22 de dezembro de 1949, da Diretoria Geral de Aeronáutica Civil, autorizou o estabelecimento de uma linha aérea provisória entre Itajaí e Joinville, por quatro meses, por meio de um Lockheed Electra. A previsão era realizar voos diários, excluindo os domingos. ${ }^{87}$

Nas décadas seguintes, a VARIG ampliou seus voos em Santa Catarina, atuando até a data da sua falência, em 2006.

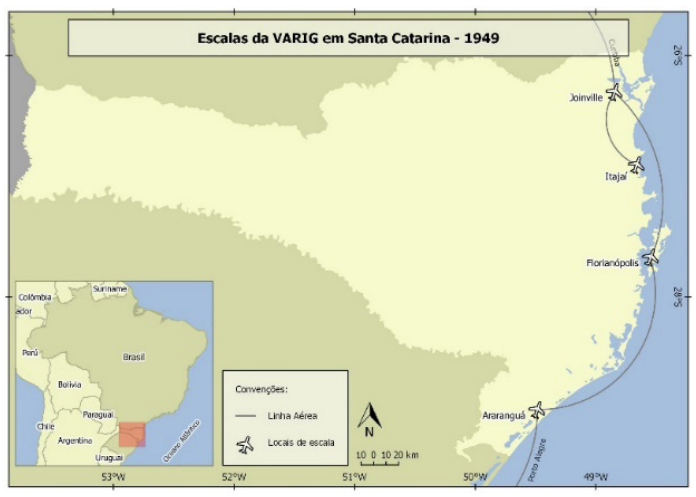

\section{Real Transportes Aéreos}

A Real Transportes Aéreos foi uma companhia paulista fundada em 1945 e adquirida pela VARIG em 1961. Teve um crescimento exponencial em poucos anos, por meio de aquisições de diversas companhias aéreas regionais. Chegou a operar com uma frota de 68 aeronaves, cobrindo quase todo o território nacional. 88

A Real iniciou seus voos em Florianópolis em junho de 1947, tendo como agente a Oliveira \& Cia, localizada na rua João Pinto, $\mathrm{n}^{\circ} 18$. Nas segundas e sextas, os Douglas DC-3 ou os Bristol Wayfarer faziam escalas na capital catarinense na rota Porto Alegre a Rio de Janeiro, com paradas em Curitiba e São

\footnotetext{
${ }^{85}$ O ESTADO. Propaganda da VARIG. Florianópolis, 02/07/1949. Disponível em: <http://bndigital.bn.gov.br/ hemeroteca-digital/>. Acesso em: abr. 2020.

${ }^{86}$ DIÁRIO OFICIAL DA UNIÃO. Itinerário e horário a que se refere a portaria n. 340, desta data, SA Viação Aérea Riograndense (VARIG): linha aérea provisória Joinville-Itajaí. Rio de Janeiro: Imprensa Oficial, 28/12/1949. Disponível em: <https://www.jusbrasil.com.br/diarios/DOU/1949/12/28 >. Acesso em: abr. 2020.

${ }^{87}$ DIÁRIO OFICIAL DA UNIÃO. Itinerário e horário a que se refere a portaria n. 340, desta data, SA Viação Aérea Riograndense (VARIG): linha aérea provisória Joinville-Itajaí. Rio de Janeiro: Imprensa Oficial, 28/12/1949. Disponível em: <https://www.jusbrasil.com.br/diarios/DOU/1949/12/28 >. Acesso em: abr. 2020.

${ }^{88}$ DAVIES, Ronald Edward George. Airlines of Latin America Since 1919. Washington, DC: Smithsonian Institution Press, 1984.
} 
Paulo. ${ }^{89}$ Em seguida, foi incluída a escala nas quartas. A Real se apresentava como a empresa que tinha a maior linha comercial do Brasil e que dispunha de um "novo padrão de conforto e segurança". ${ }^{00}$

Em março de 1948, a Real suspendeu os voos para Santa Catarina, sem esclarecer os motivos. ${ }^{91}$ Nessa mesma época, a capital catarinense já era área atendida pela Panair, Cruzeiro do Sul e VARIG, com voos diários para Porto Alegre, Curitiba, São Paulo e Rio de Janeiro. Na década seguinte, a empresa voltou a frequentar os aeroportos catarinenses, mantendo seus serviços até a incorporação pela VARIG em 1961.

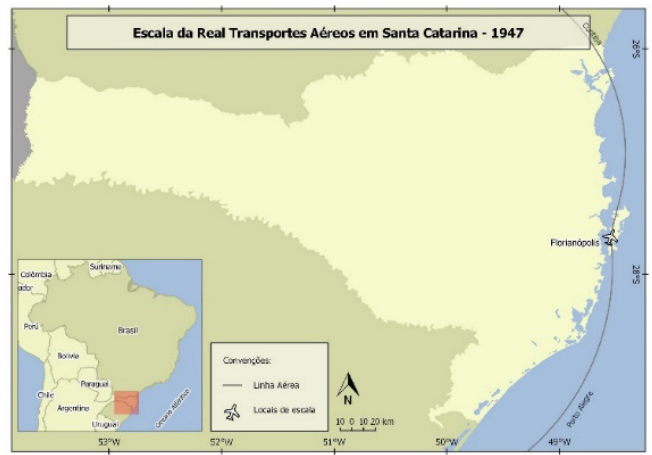

\section{Transportes Aéreos Bandeirantes Ltda (TABA)}

A Transportes Aéreos Bandeirantes Ltda (TABA), fundada em 1945, na cidade do Rio de Janeiro, iniciou suas operações em início de abril de 1948, com a linha Rio de Janeiro-Laguna, com escalas em Paraty, Santos, Cananeia, Paranaguá, São Francisco do Sul, Itajaí e Florianópolis. A rota era realizada por dois Consolidated PBY-5 Catalina, com capacidade para 20 passageiros, adquiridos da Viação Aérea Santos Dumont..$^{92}$

${ }^{89}$ O ESTADO. Real SA Transportes Aéreos. Florianópolis, 12/06/1947. Disponível em: <http://bndigital.bn.gov. $\mathrm{br} /$ hemeroteca-digital/>. Acesso em: abr. 2020.

${ }^{90}$ O ESTADO. Anúncio da Real SA Transportes Aéreos. Florianópolis, 17/08/1947. Disponível em: <http:// bndigital.bn.gov.br/hemeroteca-digital/>. Acesso em: abr. 2020.

${ }^{91}$ O ESTADO. A Praça: comunicado da Real SA Transportes Aéreos. Florianópolis, 14/03/1948. Disponível em: <http://bndigital.bn.gov.br/hemeroteca-digital/>. Acesso em: abr. 2020.

${ }^{92}$ CORREIO DA MANHÃ. Expediente do Ministério da Viação. Rio de Janeiro, 17/03/1948. Disponível em: <http:// bndigital.bn.gov.br/hemeroteca-digital/>. Acesso em: abr. 2020.

${ }^{93}$ CORREIO DA MANHÃ. Anúncio da TABA. Rio de Janeiro, 04/04/1948. Disponível em: <http://bndigital. bn.gov.br/hemeroteca-digital/>. Acesso em: abr. 2020. 
As viagens em direção ao Sul eram realizadas nas terças e sextas, às 13h; para o Norte, nas quartas e nos sábados, às $8 \mathrm{~h}$. Em agosto, a linha foi estendida até Porto Alegre, com escala na cidade de Araranguá, que conecta-se com Criciúma, Urussanga e Siderópolis pela Estrada de Ferro Dona Teresa Cristina. ${ }^{94}$ Portanto, as linhas da TABA também reforçaram o processo de litoralização, mas ao mesmo tempo consolidavam a desconcentração aeroportuária em Santa Catarina. Até porque o equipamento utilizado era um hidroavião, em uma época de difusão em massa do Douglas DC-3. Em Florianópolis, o agente responsável pelos serviços da TABA, que também incluía mala postal, era $Z$. L. Steiner \& Cia, situado na rua Álvaro de Carvalho. Em São Francisco do Sul, o agente era Oromtes Maia.

A TABA teve sua licença para voar suspensa temporariamente logo após o acidente que envolveu seu hidroavião Catalina, nas proximidades de Iguape, em 30 de setembro de 1949. O acidente resultou na morte de quatro passageiros, dos vinte que ocupavam a aeronave. ${ }^{95} \mathrm{Em} 22$ de setembro, o DAC suspendeu os voos da TABA, alegando falta de segurança. ${ }^{96} \mathrm{~A}$ empresa voltou a operar em seguida com um Douglas DC-3 realizando a mesma rota e as escalas. Em Santa Catarina operou até 1959, sendo adquirida pela VASP em 1963.

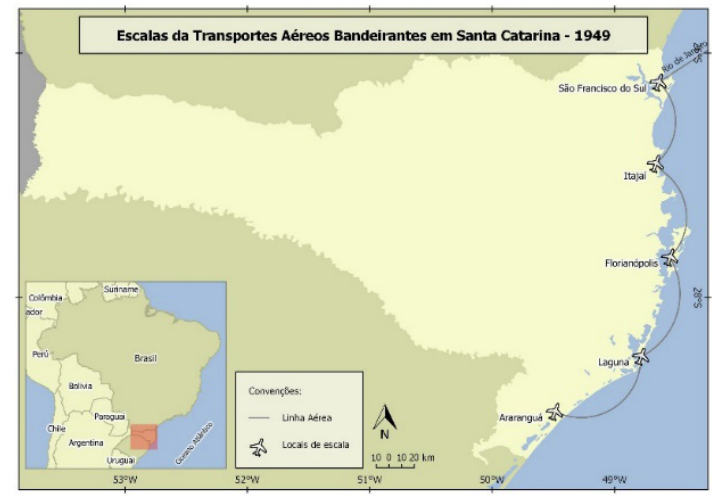

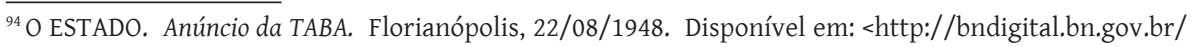
hemeroteca-digital/>. Acesso em: abr. 2020.

${ }^{95}$ A NOITE. O desastre de aviação ocorrido em Iguape. Rio de Janeiro, 01/10/1949. Disponível em: <http:// bndigital.bn.gov.br/hemeroteca-digital/>. Acesso em: abr. 2020.

${ }^{96}$ A NOITE. Suspensa de operar voos. Rio de Janeiro, 23/09/1949. Disponível em: <http://bndigital.bn.gov. $\mathrm{br} /$ hemeroteca-digital/>. Acesso em: abr. 2020. 


\section{Considerações finais}

A evolução dos transportes aéreos no Brasil seguiu o mesmo rumo do processo de ocupação e de definição do território nacional: iniciou com voos e escalas na costa litorânea, seguiu em direção ao interior, avançou para o sertão, chegou ao planalto central e, por fim, alcançou a Amazônia. Esse mesmo movimento foi seguido em Santa Catarina na formação da sua rede aeroviária por meio da definição de linhas e da construção de aeroportos em diversas cidades do litoral, planalto e oeste. No período ora analisado, 1927 a 1949, as escalas em Santa Catarina se concentram mais próximo ao litoral, à exceção de Blumenau. Afinal, na rota entre Rio de Janeiro e Porto Alegre, o caminho natural seria pelo litoral, uma vez que eram utilizados, principalmente, hidroaviões. Na década seguinte, a "era da aviação regional", as linhas foram estendidas para Lages, Joaçaba e Chapecó.

Essa rota litorânea reforçou o longo processo de litoralização que estava em marcha em Santa Catarina por meio de movimentos demográficos, urbanização, formação dos sistemas regionais de economia, sobreposição das camadas geoeconômicas e institucionalização das diversas esferas da existência. Ao longo dessa grande área litorânea, que abrange o litoral sul, leste e litoral norte catarinense, formou-se uma tríade territorial composta por cidades industriais, cidades portuárias e a cidade administrativa. Vinculados às cidades industriais e às portuárias estavam os sistemas regionais de economia, que na combinação com as camadas geoeconômicas adensaram o Estado e o capital no território.

São Francisco do Sul, cidade portuária por onde era escoada a erva mate e a madeira proveniente do planalto catarinense, conectava-se com a cidade industrial de Joinville, centro comercial e financeiro do complexo ervateiro, por meio da navegação fluvial e ferroviária. Itajaí, cidade portuária, responsável pelas exportações da produção têxtil, madeireira e manufatureira do vale do Itajaí, mantinha contato com Blumenau por meio da navegação do rio Itajaí-Açu. Laguna, outra cidade portuária, inicialmente foi responsável pelo escoamento da produção carbonífera advinda das minas da região de Criciúma e Urussanga, cuja integração era realizada pela estrada de ferro.

Portanto, as escalas realizadas pelas diversas companhias aéreas que sobrevoavam Santa Catarina também estão relacionadas à formação dos sistemas regionais de economia e à disponibilidade de fluxos gerados pelas atividades econômicas e pela urbanização. Sendo assim, os estudos sobre aviação, um 
tipo específico de camada geoeconômica, constituem-se em mais um capítulo relevante para pensarmos a formação econômica de Santa Catarina.

\section{Referências}

BRASIL. Relatório do Ministério da Marinha apresentado ao Presidente da República pelo Ministro Alexandrino Faria de Alencar em maio de 1923. Rio de Janeiro: Imprensa Naval, 1923. Disponível em: <http://ddsnext.crl.edu/titles/>. Acesso em: abr. 2020.

DAVIES, Ronald Edward George. Airlines of Latin America Since 1919. Washington, DC: Smithsonian Institution Press, 1984.

GOULARTI FILHO, Alcides. Formação do complexo e do sistema estatal catarinense. In: VII Jornadas Uruguayas de História Económica. Montevidéu: AUDHE, dez. 2019. GOULARTI FILHO, Alcides. Formação econômica de Santa Catarina. Florianópolis: Editora da UFSC, 2016.

GOULARTI FILHO, Alcides. Porto, ferrovias e navegação em Santa Catarina. Florianópolis: Editora da UFSC, 2013.

PILEGGI, Aristides. VASP: seus dez primeiros anos de vida. In: Revista do Instituto Histórico e Geográfico de São Paulo. São Paulo: IHGSP, v. LXXVIII, p. 323-362, 1982.

TAYLOR, John William Ransom. A evolução da aviação. São Paulo: Melhoramentos, 1982.

Artigo recebido para publicação em 20/11/2020

Artigo aprovado para publicação em 24/09/2021 